\title{
Monetary Policy and Economic Performance Since the Financial Crisis
}

\author{
Dario Caldara, Etienne Gagnon, Enrique Martínez-García, and Christopher I. Neely
}

\begin{abstract}
The analysis in this article was presented to the Federal Open Market Committee as background for its discussion of the Federal Reserve's review of monetary policy strategy, tools, and communication practices. The Committee discussed issues related to the review at five consecutive meetings from July 2019 to January 2020. References to the Federal Open Market Committee's current framework for monetary policy refer to the framework articulated in the "Statement on Longer-Run Goals and Monetary Policy Strategy" first issued in January 2012 (FOMC, 2021).
\end{abstract}

We review the macroeconomic performance during the Global Financial Crisis and subsequent economic expansion, as well as the challenges in the pursuit of the Federal Reserve's dual mandate. We characterize the use of forward guidance and balance sheet policies after the federal funds rate reached the effective lower bound. We also review the evidence on the efficacy of these tools and consider whether policymakers might have used them more forcefully. Finally, we examine the postcrisis experience of other major central banks with these policy tools. (JEL E31, E32, E52, E58)

Federal Reserve Bank of St. Louis Review, Fourth Quarter 2021, 103(4), pp. 425-60.

https://doi.org/10.20955/r.103.425-60

\section{INTRODUCTION}

In this article, we summarize macroeconomic outcomes during the Global Financial Crisis (GFC) and subsequent economic expansion from the point of view of the Federal Reserve's dual mandate. Unemployment rose sharply during the crisis and declined steadily thereafter, whereas inflation persistently fell short of the symmetric 2 percent longer-run inflation goal adopted in January 2012. We highlight that departures from mandated goals reflect structural changes - some preceding the GFC, others brought about by the shock of the GFC - that took time to recognize and may have inhibited the policy response. We then review the evolving policy response through the increasingly forceful use of balance sheet

Dario Caldara is the chief of the Trade and Financial Studies Section and an economist and Etienne Gagnon is the assistant director of the Program Direction Section and an economist at the Board of Governors of the Federal Reserve System. Enrique Martínez-García is a senior research economist and policy advisor at the Federal Reserve Bank of Dallas. Christopher J. Neely is a vice president and economist at the Federal Reserve Bank of St. Louis.

(c) 2021, Federal Reserve Bank of St. Louis. The views expressed in this article are those of the author(s) and do not necessarily reflect the views of the Federal Reserve System, the Board of Governors, or the regional Federal Reserve Banks. Articles may be reprinted, reproduced, published, distributed, displayed, and transmitted in their entirety if copyright notice, author name(s), and full citation are included. Abstracts, synopses, and other derivative works may be made only with prior written permission of the Federal Reserve Bank of St. Louis. 


\section{Caldara, Gagnon, Martínez-García, Neely}

policies (BSPs) and forward guidance (FG), and we assess their efficacy, costs, and risks. We consider how perceptions of the benefits and potential costs likely shaped the deployment of these policies. We explore to what extent more-forceful use of these policies within the thenprevailing framework could have mitigated the constraints imposed by the effective lower bound (ELB) on the attainment of policy objectives.

The labor market recovery from the GFC was within the range of historical experience, with monetary policy supporting steady job gains despite impairment of some transmission channels. With respect to price stability, longer-run inflation expectations generally proved well anchored during the crisis, but inflation subsequently ran below 2 percent prior to the onset of the pandemic, and some measures of long-run inflation expectations softened to undesirably low levels.

We contend that, under the policy framework at the time, policymakers could have employed accommodation more forcefully. The fact that policymakers did not judge moreforceful policy to be appropriate, however, especially in the early years of the post-crisis period, was not a shortcoming of the framework but arguably reflected the challenges of conducting monetary policy in an uncertain economic environment using largely untested policy tools. In particular, we describe several structural transformations that were difficult to discern in real time, including a diminished sensitivity of inflation to resource slack, a decline in the natural rate of unemployment, and a decline in the neutral federal funds rate $\left(r^{*}\right)$. These transformations limited the scope of federal funds rate policies, weakened the effect of monetary policy on inflation, and revealed the labor market gap to be larger than once thought. Recognition of these changes would have strengthened the case for even greater accommodation.

The evidence shows that the BSPs and FG deployed at the ELB eased financial conditions, supported employment, and helped raise inflation toward 2 percent in a manner roughly consistent with expectations at the time, though much uncertainty remains about the size and persistence of these effects. By contrast, worries that BSPs would disrupt market functioning, induce excessive risk-taking, or fuel inflation did not materialize.

A number of foreign central banks responded to the GFC with strategies and tools that were similar to those used by the Federal Open Market Committee (FOMC). Their experiences highlight the importance of anchoring longer-term inflation expectations, the risk of potentially inconsistent policy actions, and the possibility of pursuing BSPs on a larger scale than the FOMC did.

Our article is organized as follows. In Section 2, we review macroeconomic performance during the GFC and subsequent economic expansion and discuss the challenges in recognizing structural transformations. In Section 3, we explore the extent to which the ELB constrained policymakers' ability to support the economy. We also review the evidence on the benefits and costs of BSPs and FG as well as the implications of these assessments for the amount of accommodation that policymakers could provide under the policy framework at the time. In Section 4, we draw lessons for the U.S. monetary policy framework from the experience of foreign central banks. Section 5 concludes. 


\section{U.S. MACROECONOMIC PERFORMANCE IN A CHANGING ECONOMY}

The GFC had multiple causes and aggravating factors, including negative foreign shocks, notably the European debt crisis, that hindered the ensuing recovery. Thus, in assessing the effectiveness of the policy measures taken, the question is not whether economic performance was unsatisfying - it clearly was-but rather what lessons the episode taught about the uses and risks of monetary policy tools. With the benefit of hindsight, we judge that the policies deployed achieved mixed success.

\subsection{U.S. Macroeconomic Performance in the Aftermath of the Global Financial Crisis}

Figure 1 shows that the GFC led to an acute rise in the unemployment rate and a marked step-down in inflation in the fall of 2008. The unemployment rate peaked at 10 percent in 2009 , 5 percentage points above the median longer-run value in the Summary of Economic Projections (SEP). 1 Sharp drops in energy and food prices dragged headline PCE (personal consumption expenditures) inflation well below the median SEP longer-run estimate of 2 percent.

In the recovery phase, the economy absorbed the recessionary labor market slack at a pace within the range experienced in the past few recoveries. In particular, the unemployment rate declined 0.75 percentage points per year, on average, from its peak in late 2009 until it reached estimates of its longer-run level around 2015. This pace was faster than the corresponding averages in the previous two labor market recoveries, at about 0.50 percentage points per year, but slower than the average in the recovery from the 1981-82 recession, at about 1 percentage point per year. 2 Whether the labor market could have recovered faster-say, as fast as during the early 1980 s-is unclear because the crisis probably impaired some of the transmission channels of monetary policy. In any case, limitations of, and lags in, the transmission of monetary policy would have precluded the economy from quickly and fully absorbing the labor market slack created by the GFC. The unemployment rate dropped to its lowest level in mid-2018 and remained there until early 2020, with labor force participation moving above its trend. 3

Figure 2 shows that longer-run inflation expectations were stable during the GFC and the early years of the recovery. Survey-based measures-such as the University of Michigan Surveys of Consumers (Michigan Surveys) median inflation projections for the next 5-to-10 years, and the Survey of Professional Forecasters (SPF) median 6-to-10-years ahead-remained near pre-GFC levels. Although the measure of inflation compensation based on Treasury Inflation-Protected Securities slid during the depths of the crisis, it quickly retraced its losses at the end of the recession. The anchoring may have helped maintain inflation closer to the 2 percent target than historical experience would suggest, given ample resource slack. $\underline{4}$ It also helped support real activity and employment because reductions in nominal interest rates passed through, almost one for one, to lower expected real interest rates.

On the negative side, real activity and the productive capacity of the economy grew modestly for many years. Moreover, PCE inflation ran below 2 percent for most of the decade after the GFC, raising concerns that longer-run inflation expectations could have become unanchored 


\section{Figure 1}

\section{Macroeconomic Outcomes}

\section{A. Unemployment rate}

Percent

10

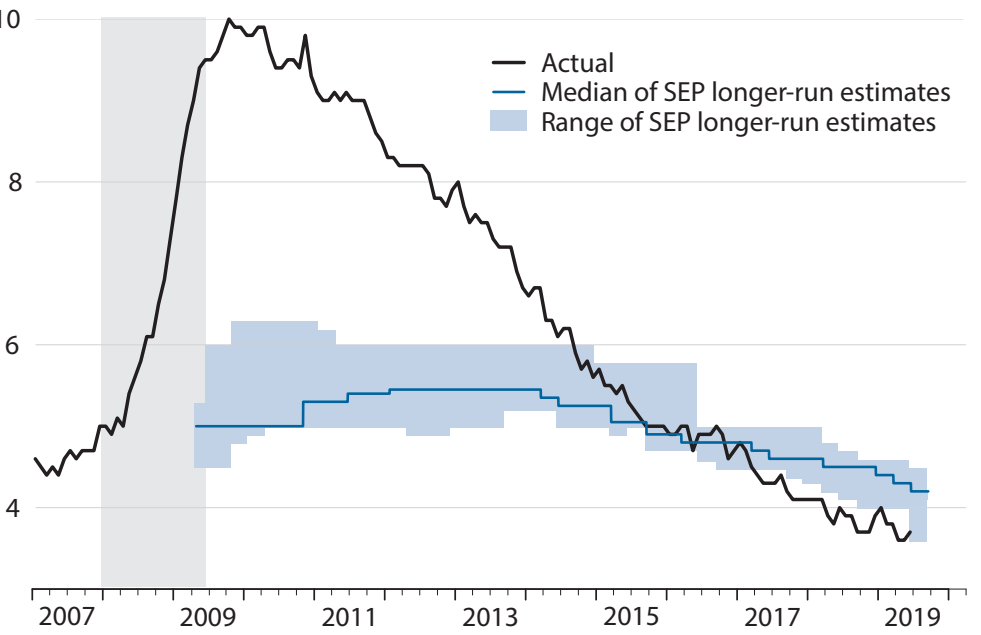

\section{B. PCE inflation}

Percent

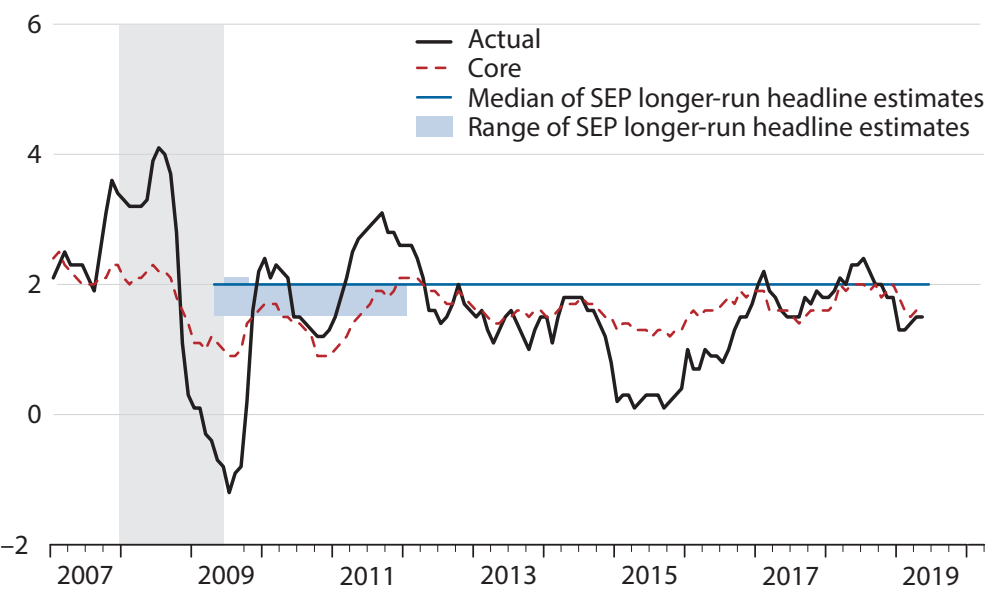

NOTE: Headline and core PCE inflation are shown on a 12-month basis and the unemployment rate on a monthly basis. The gray bars indicate a recession as determined by the National Bureau of Economic Research.

SOURCE: Federal Reserve Board; FRED ${ }^{\circledR}$, Federal Reserve Bank of St. Louis. 


\section{Figure 2}

\section{U.S. Long-Term Inflation Expectations and Compensation}

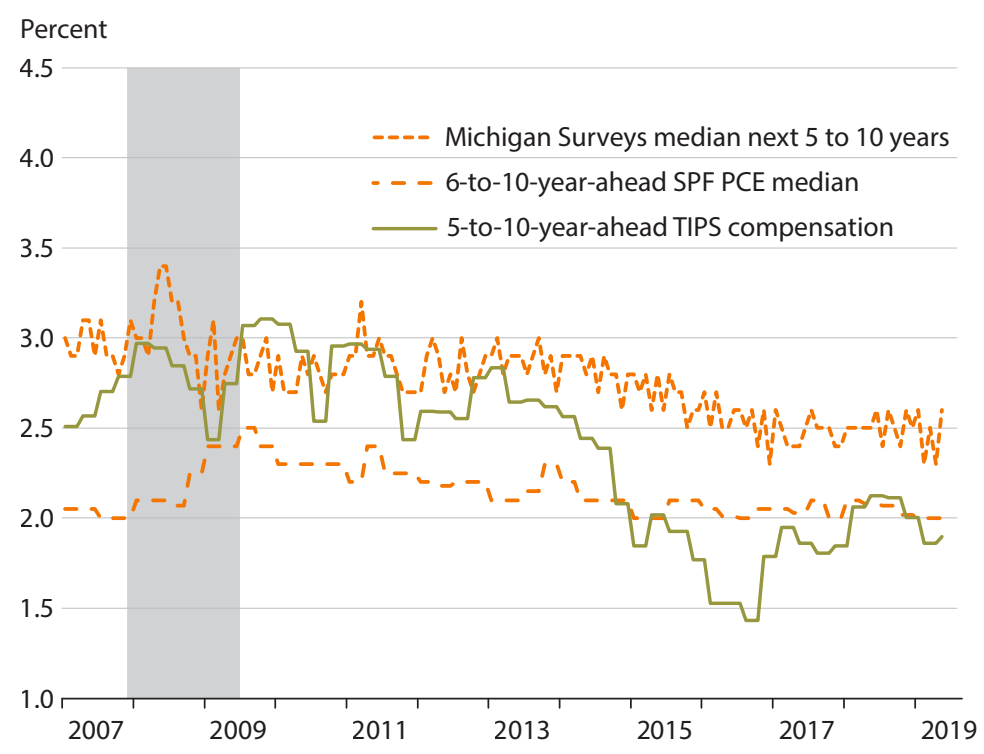

NOTE: Treasury Inflation-Protected Securities (TIPS) compensation values are based on comparisons of an estimated TIPS yield curve with an estimated nominal off-the-run Treasury yield curve, with an adjustment for the indexation lag effect. The gray bar indicates a recession as determined by the National Bureau of Economic Research.

SOURCE: Michigan Surveys, University of Michigan Surveys of Consumers; SPF, Federal Reserve Bank of Philadelphia; TIPS, Federal Reserve Board staff calculations.

or anchored at too low a level. Some survey-based measures of longer-run inflation expectations (such as the Michigan Surveys measure shown in Figure 2) and measures of inflation compensation ran below their pre-GFC trend and possibly below levels consistent with the 2 percent goal. In mid-2014, the Board of Governors of the Federal Reserve System's staff Tealbook projection became conditioned on the explicit assumption that "underlying inflation"-defined as the level of PCE inflation that would prevail in the absence of slack or other shocks-was below 2 percent. ${ }^{5}$ In short, longer-run inflation expectations appeared to be lower than the FOMC's target. Letting inflation expectations remain below target can hamper achievement of the dual mandate. As we discuss later, the Bank of Japan (BOJ) struggled to raise inflation expectations, which fueled weak inflation and exposed the economy to adverse shocks.

\subsection{Did the U.S. Economy Behave as in the Past?}

A number of structural transformations occurred over the past decade that could only be recognized over time.

2.2.1 Fall in the Natural Rate of Unemployment. The paucity of price and wage pressures as slack disappeared suggests that the labor market had more room to run than previously thought. From 2015 to 2019, the median SEP value for the unemployment rate in the longer 
Figure 3

\section{Long-Run Estimates of Real Neutral Interest Rates}
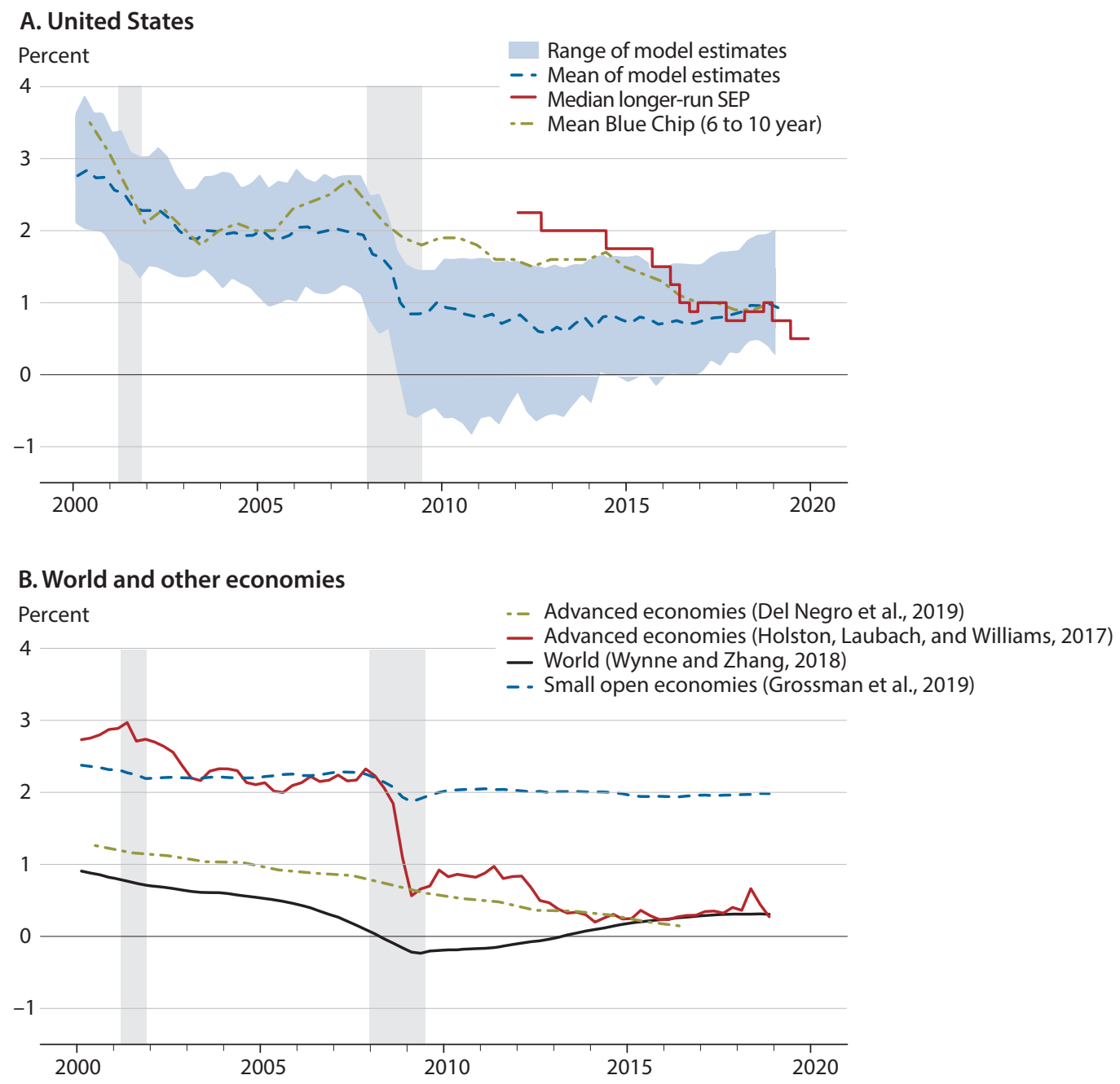

NOTE: All estimates are one sided, with the exception of Del Negro et al. (2019), which is two sided. The statistics in Panel A are based on eight time-series models maintained by Federal Reserve System staff. The gray bars indicate recessions as defined by the National Bureau of Economic Research. Mean Blue Chip (6-to-10-year) values are deflated by corresponding values for the GDP deflator.

SOURCE: Federal Reserve Board; National Bureau of Economic Research; and Wolters Kluwer Legal and Regulatory Solutions U.S., Blue Chip Economic Indicators. 


\section{Figure 4}

\section{Forecast Revisions}

\section{A. Unemployment rate}

Percent

10

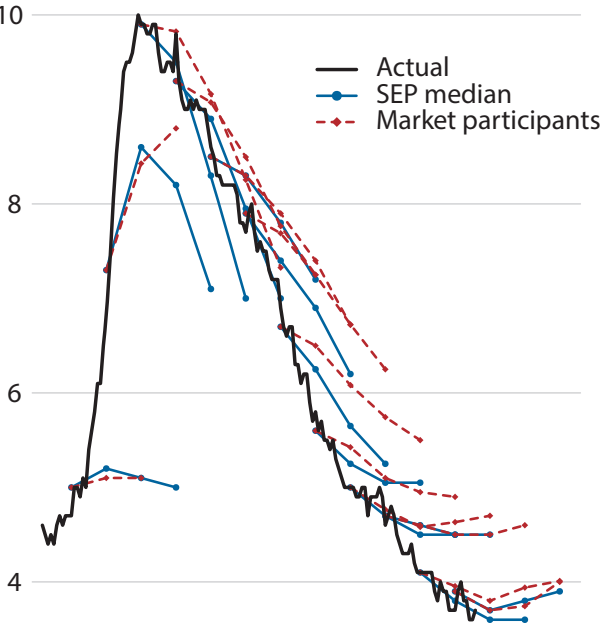

20072010201320162019

\section{Headline inflation}

Four-quarter percent change

5
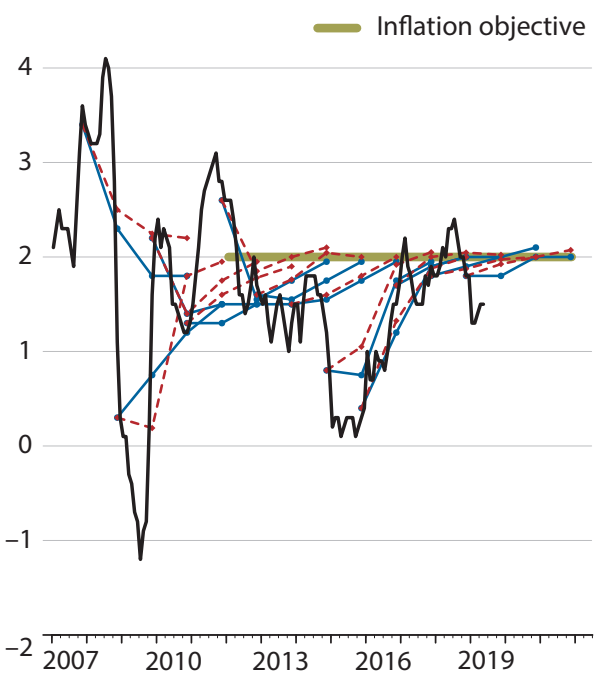

\section{B. Real GDP growth}

Four-quarter percent change

5
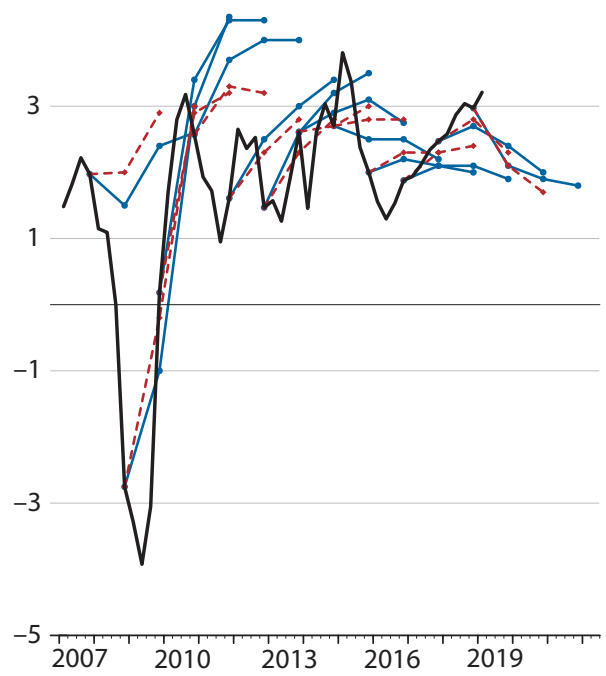

D. Federal funds rate

Percent

6

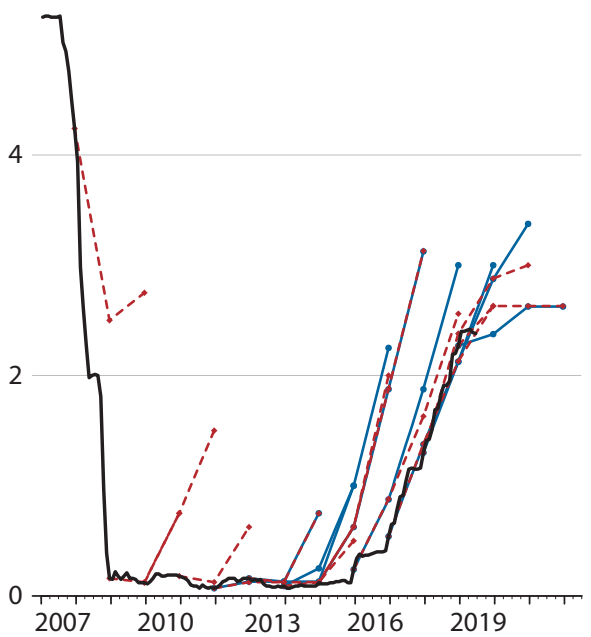

NOTE: SEP medians correspond to projections made in the first quarter of each year. Where unavailable, we approximate SEP medians with the midpoints of central tendencies. In January 2012, the FOMC established a longer-term inflation goal and began reporting participants' policy rate assumptions. Market participants' values are from the Survey of Professional Forecasters for the unemployment rate and PCE inflation, the Blue Chip Economic Indicators for real GDP growth, and the Survey of Primary Dealers for the federal funds rate.

SOURCE: FRED ${ }^{\circledR}$, Federal Reserve Bank of St. Louis; Federal Reserve Board; Survey of Professional Forecasters, Federal Reserve Bank of Philadelphia; Survey of Primary Dealers, Federal Reserve Bank of New York; and Blue Chip Economic Indicators, Wolters Kluwer Legal and Regulatory Solutions U.S. 
run fell from 5.5 percent to 4.2 percent (see Figure 1). Factors such as population aging, rising educational attainment, or other aspects of human capital formation may have reduced the natural rate. $\underline{6}$

2.2.2 Step-Down in the Trend Rate of Productivity Growth. Real output per hour in the business sector grew a little less than 1.25 percent annually during the post-GFC economic expansion, half its pace during the previous two economic expansions. ${ }^{?}$

2.2.3 Decline in $r^{*}$. As Figure 3 shows, time-series estimates of $r^{*}$, both in the United States and abroad, declined notably from their pre-GFC levels. The median SEP estimate fell from 2.25 percent in the first quarter of 2012 (when this information was first gathered) to only 0.5 percent during the second half of 2019. A decline in $r^{*}$ could reflect factors such as an aging population, the step-down in the pace of productivity growth, and lower risk tolerance. $\underline{8}$

2.2.4 Diminished Sensitivity of Inflation to Resource Slack. Inflation has become less sensitive to contemporaneous movements in domestic resource slack and less persistent, so that a given movement in resource slack today will result in a smaller cumulative price response than previously. A decline in sensitivity need not imply a structural change: A monetary policy that stabilizes inflation weakens the correlation between inflation and resource slack. ${ }^{2}$ However, policymakers' continued difficulties in raising inflation to 2 percent despite extraordinary policy actions suggest that structural change partly explains the diminished sensitivity.

Identifying the transformations in real time is an inherently challenging task, and there remains substantial uncertainty about these phenomena and their evolution. Policymakers and market participants learned only slowly about these transformations through their forecast errors. Figure 4 illustrates that, during the economic recovery, policymakers and market participants systematically underpredicted the speed at which the unemployment rate fell and overpredicted real gross domestic product (GDP) growth - that is, their projections implied overly optimistic views of labor productivity growth. $\underline{10}$ It also shows that market participants were repeatedly disappointed by the failure of inflation to rise to 2 percent over the medium term as the labor market tightened. By contrast, FOMC participants generally saw medium-term inflation falling short of 2 percent under appropriate policy during much of the recovery, including for a few years after they adopted 2 percent as their longer-run goal. $\underline{11}$

Structural transformations can call for changes in the conduct of monetary policy to achieve the dual mandate. Earlier recognition of these structural transformations might have strengthened the case for more accommodative policies. Consistent with this conjecture, Figure 4 shows that market participants and policymakers repeatedly deferred the projected liftoff date, as they concluded that the labor market had greater room to run and that $r^{*}$ had fallen more than they had previously assumed. 


\section{DEPLOYMENT OF THE FEDERAL OPEN MARKET COMMITTEE'S POLICY TOOLS}

The rapid worsening of the economic outlook in the fall of 2008 led the FOMC to slash the target for the federal funds rate to a range of 0 to 25 basis points. The simple rules in Yellen (2017) prescribed lowering the policy rate to between -1.5 and -9 percent during the GFC. The FOMC judged using a cost-benefit analysis, including practical and legal considerations, that negative deposit rates were unappealing. 12 Accordingly, the FOMC used BSPs and FG to provide additional monetary stimulus. $\underline{13}$

The Federal Reserve's BSPs comprised three large-scale asset purchase (LSAP) programs (henceforth LSAP1, LSAP2, and LSAP3) and a maturity extension program. These programs focused on purchases of long-term Treasury bonds, agency mortgage-backed securities (MBS), or both, with gross purchases totaling $\$ 4.65$ trillion. The FOMC also attempted to manage expectations about future policy with FG. From December 2008 to the summer of 2011, FG was of a qualitative nature, conveying the FOMC's anticipation that short-term interest rates would remain low "for some time" or "for an extended period." In August 2011, the FOMC switched to a calendar-based approach that emphasized its expectation that the funds rate would remain exceptionally low at least until some preannounced date. Then, in December 2012, the FOMC began using a threshold-based approach that signaled a low policy rate for at least as long as unemployment and inflation stayed above or below preannounced values. $\underline{\underline{14}}$

\subsection{Did Balance Sheet Policies and Forward Guidance Lead to Better Outcomes?}

There is broad consensus that BSPs and FG helped at least partially overcome the ELB constraint. For example, Eberly, Stock, and Wright (2020) argue that BSPs and FG reduced the unemployment rate by as much as 2 percentage points and raised inflation a few tenths of 1 percentage point in the first years of the recovery. $\frac{15}{}$ That said, researchers debate the effectiveness of BSPs and FG. Some observers argue that BSPs and FG fully substituted for the shortfall, so that the ELB did not really constrain the response to the GFC, while other observers see alternative policy tools as having had little, if any, positive macroeconomic effects (see our review of estimates below). $\underline{16}$ The majority view is that BSPs and FG made up for some, though not all, of the shortfall.

\subsection{Were the Efficacy and Costs of Balance Sheet Policies and Forward Guidance as Expected?}

In memos sent to the FOMC in late 2008, the Federal Reserve Board's staff judged that BSPs would likely support the economy by reducing borrowing costs for the private sector and by exerting downward pressure on the exchange value of the dollar. The staff also noted that only very large purchases would likely have the desired effects and that FG could lessen policy uncertainty and reduce longer-term interest rates. $\frac{17}{}$ However, the paucity of historical precedents and exceptionally stressed financial conditions left great uncertainty about these judgments. FOMC participants expressed similar judgments that BSPs would likely have positive effects, in addition to raising several concerns (to be discussed). Our review of the 


\section{Caldara, Gagnon, Martínez-García, Neely}

evidence on the financial and macroeconomic effects of BSPs and FG suggests that early estimates of the likely effects were in the right ballpark and that adverse side effects have been less severe than feared.

3.2.1 Financial Effects. Researchers have most often evaluated the financial effects of BSPs and FG on asset prices with event studies, to exploit the rapid reaction of asset prices to shocks, such as unexpected announcements. Market participants were surprised by the advent of LSAP1, and event studies around LSAP1 communications show large, immediate financial effects. $\underline{18}$

Depending on the study, LSAP 1 reduced the 10-year Treasury yield by 50 to 91 basis points. Table 1 presents results from Gagnon et al. (2011), showing that LSAP1 announcements reduced 10-year Treasury yields by 55 to 91 basis points, depending on the event set. Corporate yields fell even more. The magnitude of the effects is sensitive to the details of the specification but is typically large. $\frac{19}{2}$ Larger event sets tend to imply smaller policy effects. Using alternative model-based approaches, Ihrig et al. (2018) assess that, altogether, past BSPs had reduced the 10 -year term premium 100 basis points by early 2015. Other studies indicate that these declines stimulated bond issuance. $\underline{20}$ Appendix D summarizes the key findings from selected studies of financial market effects of unconventional monetary policy.

Panels B and C of Table 1 show that LSAP 1 announcements also reduced 10 year government yields in the advanced foreign economies (AFEs) by more than 40 basis points on average and depreciated the U.S. dollar relative to AFE currencies by almost 6 percent. BSP announcements also reduced market estimates of tail risk but only modestly raised equity prices (Wright, 2012).

A number of studies have found that the type of assets purchased mattered: MBS purchases particularly pushed down mortgage rates and had a greater effect on lending for banks that owned greater amounts of MBS. $\underline{21}$ Table 2 describes results from selected studies of effects of U.S. BSPs and FG on financial markets.

BSPs affect yields through several channels. Signaling reduces expected future interest rates, while duration-risk effects reduce term premiums by lowering the quantity of duration risk held by the public. A third channel, "local supply effects," reduces the yields of bonds with durations similar to those of bonds that were actually purchased. Studies disagree about the relative importance of these channels, but there is evidence that all three had economically significant effects.

Regarding FG, the qualitative guidance provided by the FOMC until mid-2011 did not induce market participants to expect a much easier path of monetary policy: As Panel D of Figure 4 makes clear, private agents continued to expect the federal funds rate to rise after four quarters. The introduction of calendar-based FG in August 2011, when the FOMC conveyed its expectations that the policy rate would stay near zero "at least through mid-2013" in its post-meeting statement (FOMC, 2011), led market participants to push back the expected liftoff from three quarters to seven quarters. Yields on 1- and 2-year Treasury securities became less responsive to economic news. $\stackrel{22}{2}$ That said, despite these developments, Del Negro, Giannoni, and Patterson (2012) argue that the August 2011 date-based FG failed to be stimulative because it was interpreted as predicting low future GDP growth, in contrast to the September 
Caldara, Gagnon, Martínez-García, Neely

\section{Table 1}

\section{The Effect of LSAP1 Events on U.S. and Foreign Yields and on the Foreign Exchange Value of the Dollar}

\begin{tabular}{|c|c|c|c|c|}
\hline & $\begin{array}{c}\text { Baseline } \\
\text { events }\end{array}$ & $p$-value & $\begin{array}{c}\text { All FOMC } \\
\text { events }\end{array}$ & $p$-value \\
\hline \multicolumn{5}{|c|}{ A. Effect on U.S. yields (basis points) } \\
\hline 2-year U.S. Treasury & -34 & & -1 & \\
\hline 10-year U.S. Treasury & -91 & & -55 & \\
\hline 10-year agency & -156 & & -134 & \\
\hline Agency MBS & -113 & & -114 & \\
\hline 10-year term premium & -71 & & -47 & \\
\hline 10-year swap & -101 & & -75 & \\
\hline Baa index & -67 & & -72 & \\
\hline
\end{tabular}

\section{B. Effect on foreign yields (basis points)}

\begin{tabular}{|c|c|c|c|c|}
\hline Australia (10 year) & -63 & $(0.01)$ & -26 & $(0.49)$ \\
\hline Canada (10 year) & -50 & $(0.00)$ & -47 & $(0.06)$ \\
\hline Germany (9 to 10 year) & -39 & $(0.01)$ & -5 & $(0.84)$ \\
\hline Japan (10 year) & -18 & $(0.04)$ & -9 & $(0.54)$ \\
\hline United Kingdom (10 year) & -43 & $(0.02)$ & -21 & $(0.46)$ \\
\hline Average effect & -42.6 & $(0.00)$ & -21.6 & $(0.23)$ \\
\hline \multicolumn{5}{|c|}{ C. Effect on exchange rate (percent) } \\
\hline AUD/USD & -6.16 & $(0.01)$ & -13.00 & $(0.00)$ \\
\hline CAD/USD & -7.76 & $(0.00)$ & -9.74 & $(0.01)$ \\
\hline EUR/USD & -6.70 & $(0.01)$ & -5.20 & $(0.19)$ \\
\hline JPY/USD & -3.54 & $(0.12)$ & -9.68 & $(0.01)$ \\
\hline GBP/USD & -5.98 & $(0.00)$ & -10.15 & $(0.00)$ \\
\hline Average effect & -5.73 & $(0.12)$ & -13.11 & $(0.03)$ \\
\hline
\end{tabular}

NOTE: Panel A is excerpted from Table 1 in Gagnon et al. (2011). It shows sums of 1-day nominal U.S. yield changes, in basis points, for two event sets: a "baseline events" set of eight LSAP1 news events (11/25/2008, 12/1/2008, 12/16/2008, $1 / 28 / 2009,3 / 18 / 2009,8 / 12 / 2009,9 / 23 / 2009$, and 11/4/2009) and an "all FOMC events" set adding all FOMC meetings and minutes releases from November 2008 through January 2010. Panels B and C are excerpted from Tables 2 and 3 , respectively, in Neely (2015). They show 1-day nominal foreign long-term yield changes and 1-day exchange rate (foreign exchange per U.S. dollar [USD]) changes for the same event sets. AUD/USD, CAD/USD, EUR/USD, JPY/USD, and GBP/USD, respectively, denote the exchange rates of Australia, Canada, the euro area, Japan, and the United Kingdom against the USD. The $p$-values show the proportions of 8-day or 13-day changes from July 2007 through January 2010 that were larger in absolute value than the actual change in the corresponding 8-day or 13-day event windows.

SOURCE: Authors' calculations. 


\section{Table 2}

\begin{tabular}{|c|c|}
\hline Study & Key finding \\
\hline Walentin (2014) & $\begin{array}{l}\text { LSAP1 increased consumption and GDP by } 3.2 \text { percent and } 3.8 \text { percent at } \\
\text { peak, respectively, largely by increasing residential investment. }\end{array}$ \\
\hline Baumeister and Benati (2013) & $\begin{array}{l}\text { LSAP1 prevented inflation dropping by } 1 \text { percentage point and output } \\
\text { growth reaching a trough of }-10 \text { percent. }\end{array}$ \\
\hline Wu and Xia (2016) & $\begin{array}{l}\text { Without the Federal Reserve's BSPs and FG, the unemployment rate would } \\
\text { have been } 1 \text { percentage point higher at peak than actually observed. The } \\
\text { macro effects of these policies are modest but nontrivial. }\end{array}$ \\
\hline Swanson (2021) & $\begin{array}{l}\text { FG, asset purchases and policy rate adjustments all have persistent effects } \\
\text { on different parts of the yield curve. }\end{array}$ \\
\hline
\end{tabular}

2012 FOMC statement, which was interpreted as a commitment to prolonged policy accommodation. The rollout of threshold-based FG in December 2012 elicited little, if any, market reaction, consistent with the FOMC's indication that the new FG was in keeping with the date-based FG it replaced.

U.S. Treasury debt issuance may have lessened the macroeconomic effects of the Federal Reserve's BSP and FG policies over time. Greenwood et al. (2014) compare the effect of the Treasury's maturity extensions on 10-year yields with those of the Federal Reserve's BSP and FG programs, using data from the end of 2007 to mid-2014. During that period, the Treasury increased the average duration of publicly held debt from 3.9 years to 4.6 years, which is consistent with its desire to reduce refinancing and rollover risk when the debt-to-GDP ratio rises. That increase in the duration of the publicly held debt offset the Federal Reserve's efforts to reduce yields. Greenwood et al. (2014) calculate that the Treasury's duration increase raised 10 -year yields by about 48 basis points, which offset about 35 percent of the Federal Reserve's BSPs and FG. $\underline{23}$ Greenwood et al. (2014) further argue that the Treasury and Federal Reserve should coordinate their efforts when the economy is at the ELB.

The results on the effects of BSPs and FG on financial markets come with several caveats. First, although monetary policy announcements can have immediate, sometimes large effects, calculating the effects of a whole program is hazardous because policy announcements are generally partially expected or generate expectations of further actions. Such leakage can render the market reaction - as judged by event studies - an inaccurate guide to the actual policy effect. Second, announcements on LSAPs probably contain signals about future short rates; hence, disentangling the effects of BSPs and FG is difficult. ${ }^{24}$ Third, event studies estimate the reaction of asset prices in a narrow window around policy announcements, typically one day, but are agnostic about the persistence of the effects. Looking over a longer horizon, Wright (2012) finds relatively short-lived effects of BSPs and FG, while Swanson (2021) finds they are very persistent. Neely (2020) criticizes Wright's (2012) model, however, arguing that it is unreliable. Finally, event studies generally rely on few key announcements, making the estimates sensitive to individual observations and obscuring statistical significance (Kuttner, 2018). 
3.2.2 Macroeconomic Effects. In contrast to the many empirical estimates of the effects of BSPs on financial conditions, relatively fewer studies quantify the effects on economic activity and inflation. The available macro studies find support for the notion that BSPs have important macroeconomic effects, but there is much uncertainty about their magnitude. Differences in estimates can be ascribed mainly to alternative modeling frameworks and assumptions about the channels through which unconventional policies stimulate the economy. Table 2 reports results from selected studies of the effects of U.S. BSPs and FG on the macroeconomy.

There are three broad classes of models used to estimate the effects of BSPs on output and inflation: dynamic stochastic general equilibrium (DSGE) models, structural vector autoregressions (SVARs), and large-scale "semi-structural" models such as the Federal Reserve's FRB/US model. Among DSGE models, Gertler and Karadi (2013) find that the peak effect of a balance sheet intervention along the lines of LSAP2 is about an additional 1 percent on the level of real output. By contrast, Chen, Curdia, and Ferrero (2012) find LSAP2 had only modest effects on output, a 0.1 percent increase. Using a SVAR, Baumeister and Benati (2013) find that the level of GDP was about 3 percent higher at its peak than it would have been absent LSAP1, while the inflation rate was about 1 percentage point higher. Weale and Wieladek (2016) find similar effects using different identifying assumptions. Engen, Laubach, and Reifschneider (2015) use the FRB/US model and find that the collective effect of all of the Federal Reserve's asset purchase programs and FG subtracted 1.2 percentage points from the unemployment rate at its peak in early 2015 and would have had a peak effect of raising inflation by 0.5 percentage points in 2016 .

3.2.3 Costs and Risks. Policymakers and analysts expressed a range of concerns regarding BSPs and FG during the debate on their use. Some worried that a huge increase in the monetary base would lead to an inflation breakout. Others worried that plentiful bank reserves might make it difficult to raise the funds target when that eventually would become necessary. Another concern was that unusual accommodation could create incentives for excessive risktaking - that is, reaching for yield - and so undermine financial stability. Adverse effects of large purchases on market functioning were also feared. For example, if the Federal Reserve were to buy most or all Treasury issues, liquidity in that market would be adversely affected. Yet another concern was that BSPs might permanently ratchet up the size of the Federal Reserve's balance sheet if subsequent economic expansions did not provide enough time for normalization. With respect to FG, FOMC participants extensively discussed the risk that their communications might be misinterpreted as unconditional commitments, might not convey the complexities of the economy and the policy process, or might downplay the datadependent nature of their policy communications. $\underline{25}$

If we look back, many of those potential risks raised by policymakers did not materialize. Worries that inflation might run above 2 percent, or that longer-run inflation expectations might become unmoored, proved to be unwarranted. Elevated reserves did not prevent raising the policy rate when it was deemed appropriate. Thanks to the Federal Reserve's ability to pay interest on excess reserves, and the creation of an overnight reverse repurchase agreement facility, the FOMC successfully raised the federal funds rate from its ELB in a context of abundant reserves starting in December 2015. Furthermore, BSPs supported market function- 
ing rather than impaired it. For example, Federal Reserve purchases of agency MBS reduced agency spreads, and LSAP announcements trimmed corporate credit risks. $\underline{26}$ Moreover, the FOMC reduced its balance sheet largely uneventfully through runoffs starting in October 2017. 27 While the "taper tantrum" episode illustrates that communicating with the public can be challenging, it is not clear that the Committee's FG created much confusion. Evidence accumulated since the crisis indicates that the costs and risks of the BSP and FG actions were probably overstated.

\subsection{Could the Committee Have Used Existing Policy Tools to Support More Stimulative Policy Under the Prevailing Framework?}

Overall, the evidence suggests that the Committee could have provided greater accommodation through BSPs and FG under its framework at the time. Specifically, the Federal Reserve's balance sheet peaked at 25 percent of GDP, a ratio lower than the European Central Bank (ECB), BOJ, and Bank of England (BOE) achieved through their LSAP programs.

Moreover, the FOMC made only moderate use of FG during the recovery, mostly to clarify the path of monetary policy. For many of the years during which the Committee employed FG, most FOMC participants projected that inflation would fall short of 2 percent and that the unemployment rate would exceed its longer-run level over the medium term. Thus, as with BSPs, FG could have been used without creating a conflict between the legs of the dual mandate. In sum, our view is that the Committee could have done more under the prevailing framework - had it chosen to do so-though further policy action would have been outside of historical experience and thus subject to considerable uncertainty regarding efficacy and risks.

We note, however, that there were limits to the extent that policymakers could have used BSPs and FG under its framework. The Federal Reserve's review of its monetary policy framework takes as given that, under the prevailing framework, policymakers use their tools to achieve the dual mandate, but they never seek to deliberately overshoot or undershoot the longer-run inflation objective, which the framework did not clarify. $\underline{28}$ Alternative "makeup" strategies would attempt to improve near-term macroeconomic conditions by making greater use of BSPs and FG, including overshooting the objective. With the exception of the BOJ's (so far unsuccessful) attempt at lifting inflation above its inflation goal, the ability to use BSPs, FG, and other tools to engineer a substantial easing of financial conditions and create expectations of future inflation running above the stated goal is largely untested.

\subsection{How Much Benefit Would Additional Accommodation Have Provided?}

Next, we discuss several counterfactual model simulations that support the argument that the FOMC might have improved inflation and employment outcomes by pursuing more accommodative policies during the recovery.

By some metrics, the Committee patiently deferred policy normalization. Figure 5 shows the results from three counterfactual simulations of the FRB/US model in which policymakers followed three Taylor-type rules, starting from 2012:Q1. The simulations suggest that following such rules would have produced worse economic outcomes. The well-known Taylor (1993) rule called for raising the federal funds rate in early 2012, which would have delayed the return 


\section{Figure 5}

\section{Counterfactual Simple Rule Policies and Outcomes}

\section{A. Nominal federal funds rate}

Percent

3.0

- Actual

... Taylor (1993) rule

_ Balanced-approach rule

2.5 - - Inertial balanced-approach rule

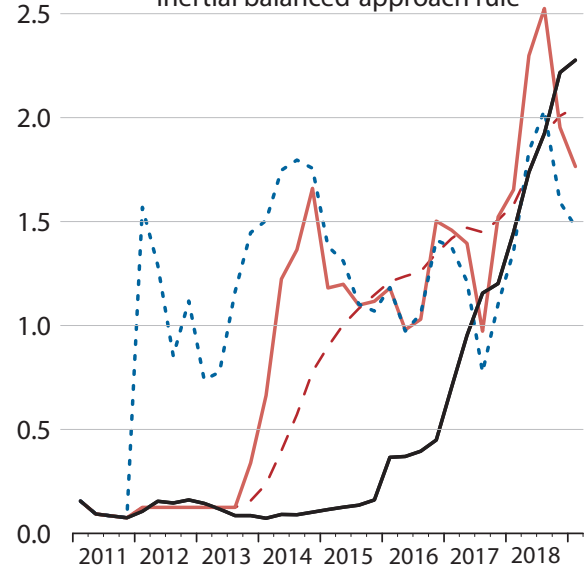

C. Real 10-year Treasury yield

Percent

2.0

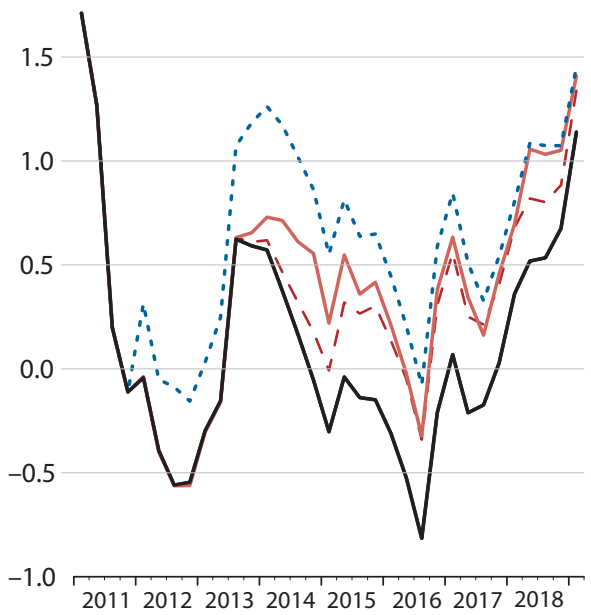

\section{B. Unemployment rate}

Percent

9.5

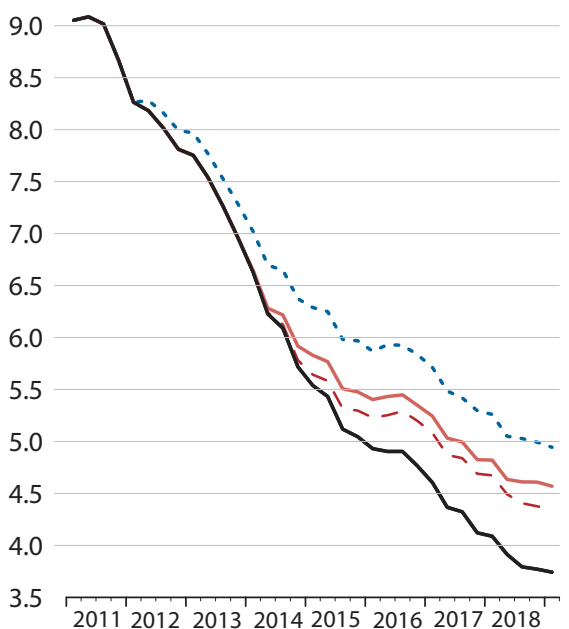

D. PCE Inflation four-quarter change

Percent

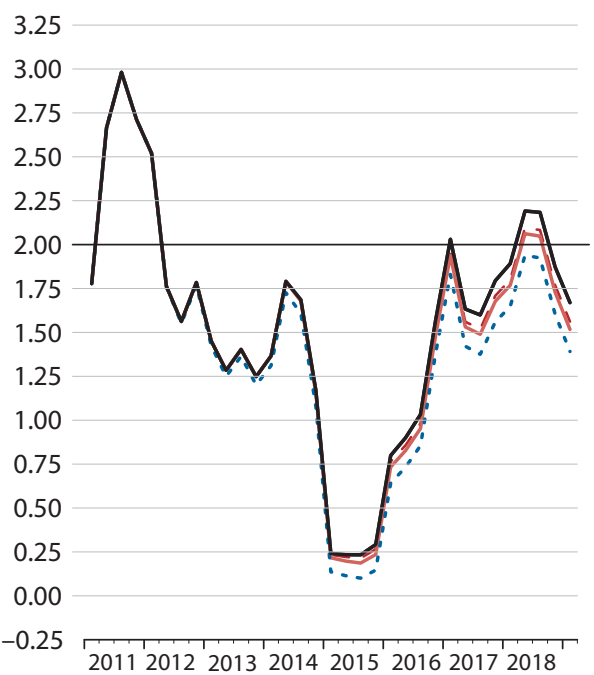

NOTE: We simulate the FRB/US model under the assumptions that agents form VAR-based expectations and that the intercepts and gaps in each policy rule are consistent with the median longer-run projections of FOMC participants over time. See Appendix A for details.

SOURCE: Authors' calculations. 
of the unemployment rate to its longer-run level by several years and led to a more pronounced undershooting of the 2 percent inflation goal. Adherence to the balanced-approach rule or its inertial version would have similarly delayed achievement of the dual mandate relative to the strategy pursued by the FOMC, though not by as much as adhering to the Taylor (1993) rule. $\underline{29}$

Given the realized evolution of the U.S. economy, other model simulations suggest that the provision of even more policy accommodation during the recovery may have improved outcomes. Eberly, Stock, and Wright (2020) use a SVAR model to compute outcomes under alternative historical paths for the federal funds rate and the 10-year term spread. They treat this spread as a policy variable that captures the combined effects of BSPs and FG on the slope of the term structure of interest rates. Their simulations suggest that policies that would have flattened the yield curve an extra 1 percentage point from late 2008 to late 2013 would have shaved a bit over 1 percentage point off the unemployment rate. However, these policies may not have pushed inflation sustainably to the 2 percent target. FRB/US simulations suggest that very large asset purchases would have been required to raise medium-term inflation even modestly. $\underline{\underline{30}}$

\section{THE INTERNATIONAL EXPERIENCE: CAUTIONARY TALES FROM EUROPE AND JAPAN}

\subsection{Macroeconomic Performance in Europe and Japan in the Aftermath of the Global Financial Crisis}

Figure 6 shows that, during the GFC, the euro area and Japanese economies suffered large contractions in economic activity and increases in unemployment, with euro area labor markets deteriorating further during the European sovereign debt crisis.

Unemployment rates eventually fell to near or below pre-GFC levels in these economies. Despite tightening labor markets, the ECB and, particularly, the BOJ have struggled to raise inflation to their targets on a sustained basis. In Japan, core inflation (excluding food and energy) averaged only 0.7 percent from the adoption of an explicit inflation target in January

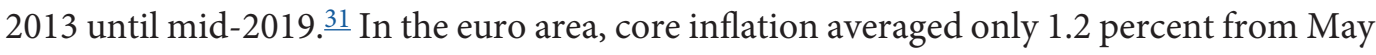
2009 until mid-2019-a level short of the ECB's mandate at the time of maintaining inflation below, but close to, 2 percent over the medium term. Longer-run Japanese inflation expectations had been well below the target level and even retraced the gains registered following the adoption of the inflation target. Euro area survey-based measures of longer-run inflation expectations were more consistent with the stated objective, but market-based inflation compensation softened to about 1.2 percent by mid-2019. By contrast, U.K. inflation averaged about 2 percent from the GFC until mid-2019, and longer-run inflation expectations were near pre-GFC levels in mid-2019. Temporary import price pressures from sterling depreciation supported U.K. inflation.

The BOJ, BOE, and ECB took substantial policy steps to raise inflation to mandated levels and to support employment and economic activity. $\frac{32}{}$ Figure 7 illustrates that the ECB cut its policy rate from 3.25 percent to 1 percent in response to the GFC and to 0.25 percent in 2014 
Caldara, Gagnon, Martínez-García, Neely

\section{Figure 6}

\section{Macroeconomic Performance of Japan, the Euro Area, and the United Kingdom}

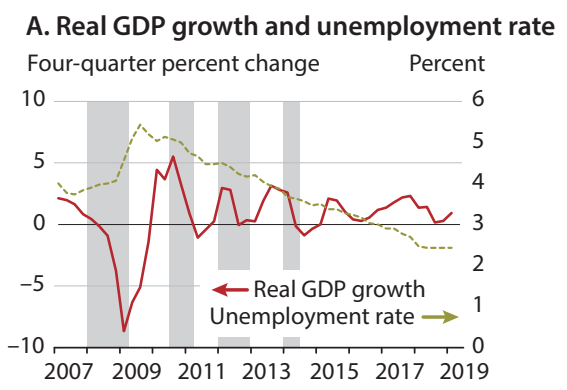

D. Real GDP growth and unemployment rate

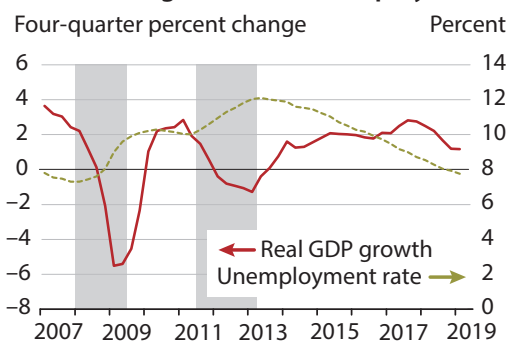

G. Real GDP growth and unemployment rate

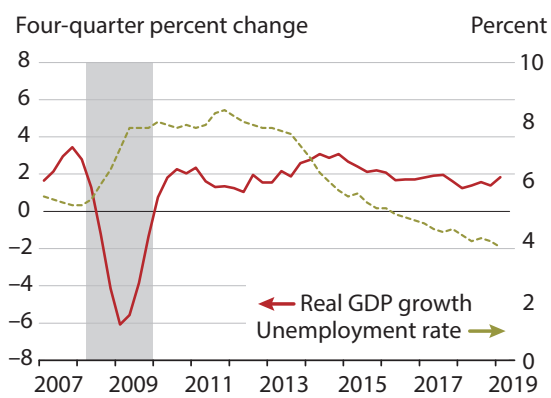

\section{Japan}

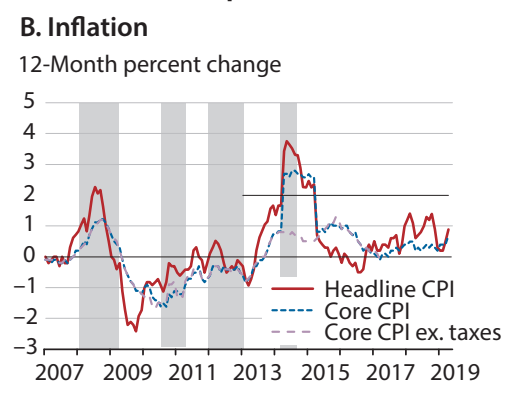

Euro area

\section{E. Inflation}

12-Month percent change

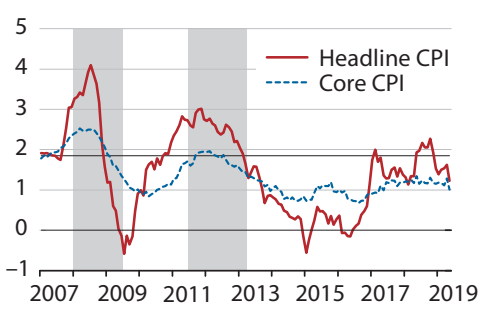

\section{United Kingdom}

\section{H. Inflation}

12-Month percent change

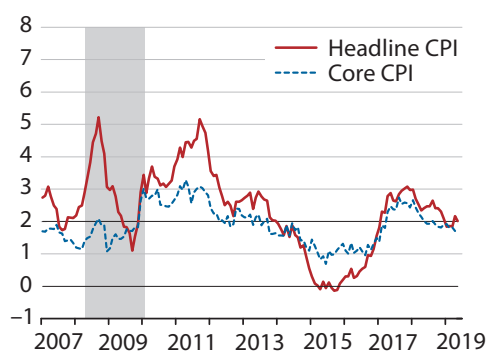

C. Long-run inflation expectations Percent

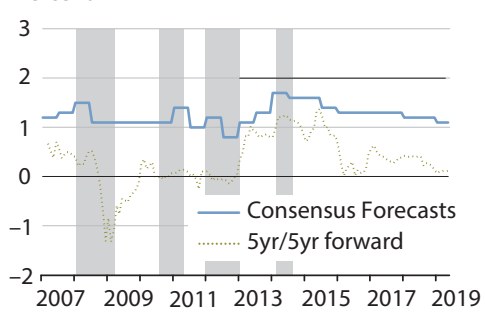

F. Long-run inflation expectations Percent

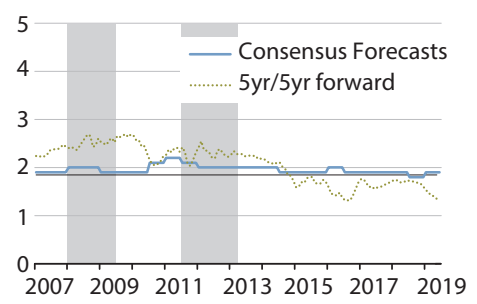

I. Long-run inflation expectations

Percent

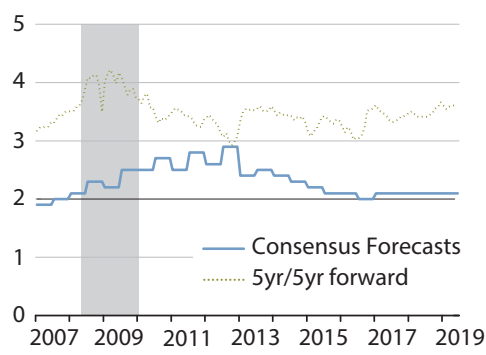

NOTE: The BOJ implemented an inflation target of 2 percent in January 2013, replacing its explicit "positive range of 2 percent or lower" in place since February 2012 (Bank of Japan, 2012). The ECB's inflation target was "close to but below" 2 percent over the medium term, which we approximate with a black line at 1.85 percent. The headline inflation measure plotted is the consumer price index (CPI) for Japan and the harmonized index of consumer prices (HICP) for the euro area and the United Kingdom. The core inflation measure plotted is the CPI excluding fresh food and energy (with and without a staff adjustment for consumption tax changes) for Japan; the HICP excluding energy and unprocessed food for the euro area; and the HICP excluding food, energy, tobacco, and alcohol for the United Kingdom. Consensus Forecasts are for the expected CPI percent change over previous year, 6 to 10 years ahead. 5yr/5yr is the market-based long-run inflation expectations of the 5-year, 5-year-forward implied inflation rate from Bloomberg. Shaded bars indicate recessions based on the chronology for each economy.

SOURCE: Bloomberg, Consensus Economics, Economic Cycle Research Institute, and Haver Analytics. 


\section{Figure 7}

\section{Policy Actions of Major Advanced Economies}
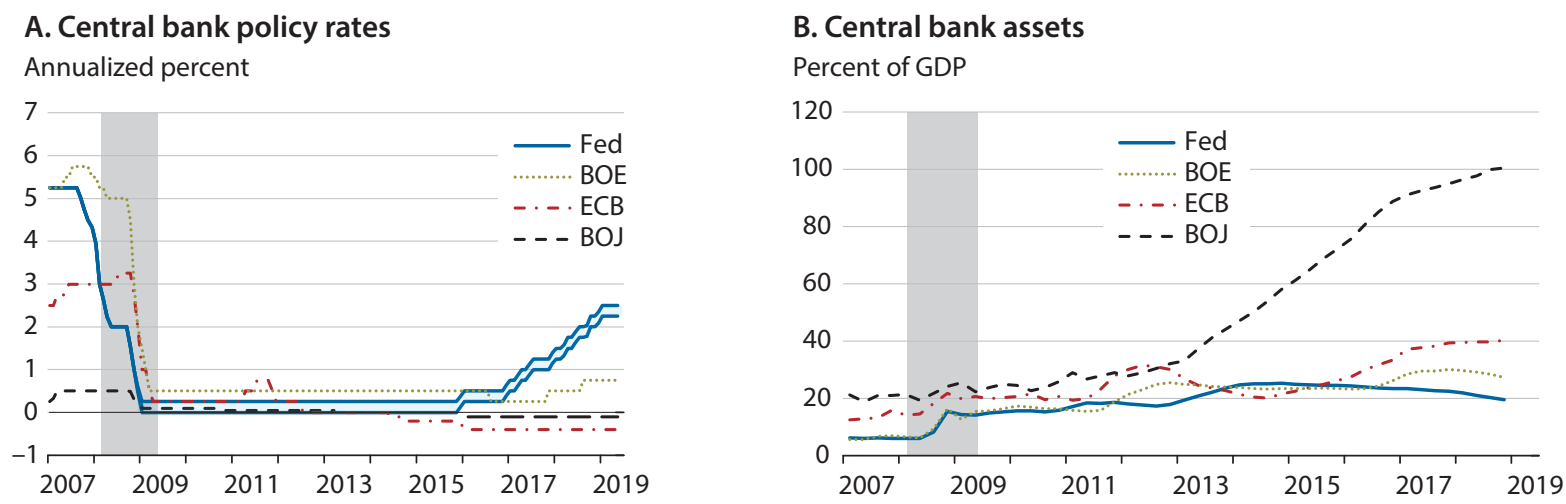

NOTE: For the Federal Reserve, the policy rate displayed is the point target for the federal funds rate before December 2008 and the target range thereafter. For the BOJ, the policy rate displayed is the overnight call rate until March 2013 and the policy rate balance rate from February 2016 onward. For the ECB and the BOE, the policy rates shown are the deposit rate and the bank rate, respectively. Central bank assets as a percent of GDP are calculated using quarterly balance sheet data from central banks and quarterly nominal GDP in local currency from national sources. Shaded bars indicate global recessions according to the chronology of Grossman, Mack, and Martínez-García (2015).

SOURCE: Haver Analytics, and Grossman, Mack, and Martínez-García (2015).

following the deepening of the European sovereign debt crisis. The BOJ entered the GFC with its policy rate very near its ELB. With policy rates near zero, these central banks deployed BSPs, FG, and other tools to provide additional policy accommodation. $\underline{33}$ The ECB expanded its balance sheet from about 13 percent of GDP in 2007 to 40 percent of GDP in 2018. The BOJ has boosted its balance sheet even more, from 21 percent of GDP in 2007 to 100 percent of GDP in 2018. Before the Brexit referendum in 2016, the BOE expanded its balance sheet in a similar proportion to the economy as did the Federal Reserve. The additional asset purchases conducted in response to Brexit raised holdings to as much as 30 percent of GDP in 2017.

As with FOMC policy actions, market participants and academics generally agree that BSPs, FG, and other measures implemented by the BOJ, BOE, and ECB eased financial conditions, supported economic activity and inflation, and put downward pressure on currencies, although these effects are imprecisely estimated. $\underline{34}$

\subsection{What Are the Lessons from the European and Japanese Experiences for the U.S. Monetary Policy Framework?}

First, the struggles of the BOJ and ECB to achieve their mandates illustrate the difficulties in raising inflation once longer-run inflation expectations become entrenched at too low of a level. Most notably, in Japan, inflation dropped from a range of 2 to 4 percent in the early 1990s to essentially zero by 1995 and was then mildly negative in most years until 2012 (Figure 8). Low inflation realizations likely eroded the public's longer-run inflation expectations, reducing incentives to raise prices and wages and thus creating a vicious circle. The $\mathrm{BOJ}$ arguably allowed deflation to become entrenched by not acting promptly and forcefully 


\section{Figure 8}

\section{Japanese Inflation and Inflation Expectations}

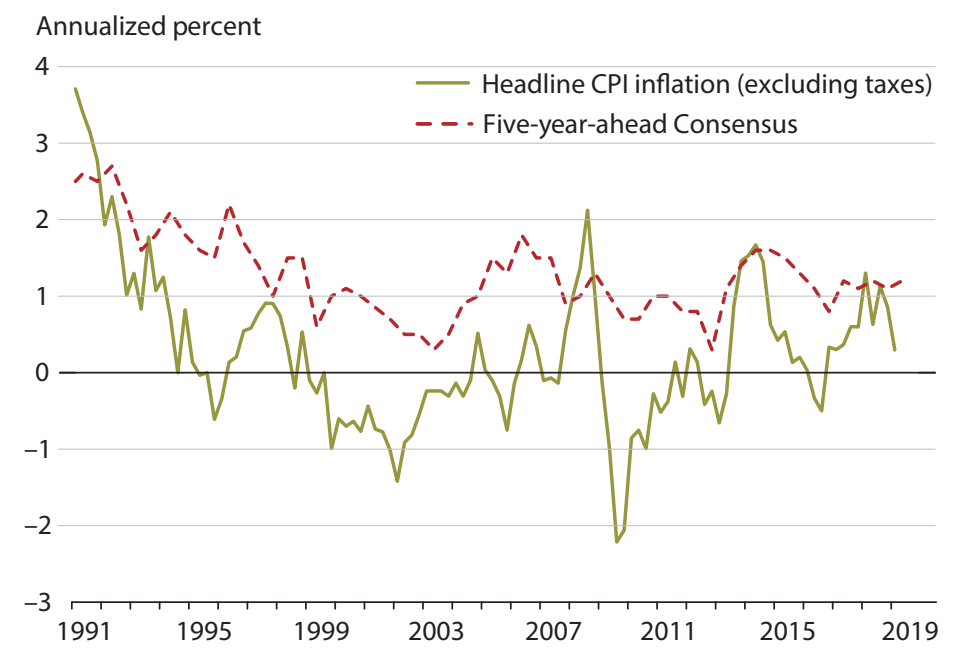

NOTE: Consumer price index (CPI) inflation adjusted by authors to exclude effects of value-added tax hikes. Actual inflation shown in four-quarter changes. The five-year-ahead Consensus is expected inflation calculated by Consensus Economics.

SOURCE: Consensus Economics, Haver Analytics, and authors' calculations.

enough, lowering its key policy rate to zero only in 1999 and initiating asset purchases in 2001-several years after the onset of deflation. The task of gauging the appropriate amount of monetary stimulus required was likely complicated by policymakers' slow recognition of a fall in $\mathrm{r}^{\star}$ and by impaired balance sheets in the banking sector that hindered the transmission of monetary policy $\cdot \frac{35}{} \mathrm{BOJ}$ communications and actions at the time also conveyed a lack of confidence in its tools and uneasiness with their deployment. $\frac{36}{}$ Some observers have argued that proximity to the ELB has created a situation in which low inflation and low GDP growth is self-fulfilling. $\frac{37}{\mathrm{BOJ}}$ officials have further suggested that a rapidly aging population and a tendency of labor and management to prioritize employment stability over wage increases have contributed to the entrenched perception that wages and prices will not rise. $\underline{38}$ It is nonetheless understood that monetary policy and low long-run inflation expectations in Japan have played a major role in creating that perception.

Second, the foreign experience with BSPs suggests that the Federal Reserve could have expanded its balance sheet further without adversely affecting market functioning and still have positive financial and macroeconomic effects at the margin. The ECB, BOE, and, especially, BOJ increased their balance sheets uneventfully to higher shares of their GDPs than did the FOMC. That said, there is some evidence that, while positive, the marginal macroeconomic effects of BSPs abroad were smaller for later programs than earlier programs. $\underline{39}$ Hence, setting aside complications regarding the subsequent balance sheet reduction, scaling up BSPs seems to have limited adverse effects, even if also perhaps limited efficacy. 


\section{Figure 9}

\section{Implications of the Effective Lower Bound Abroad for U.S. Economic Performance in a Global Recession Scenario}
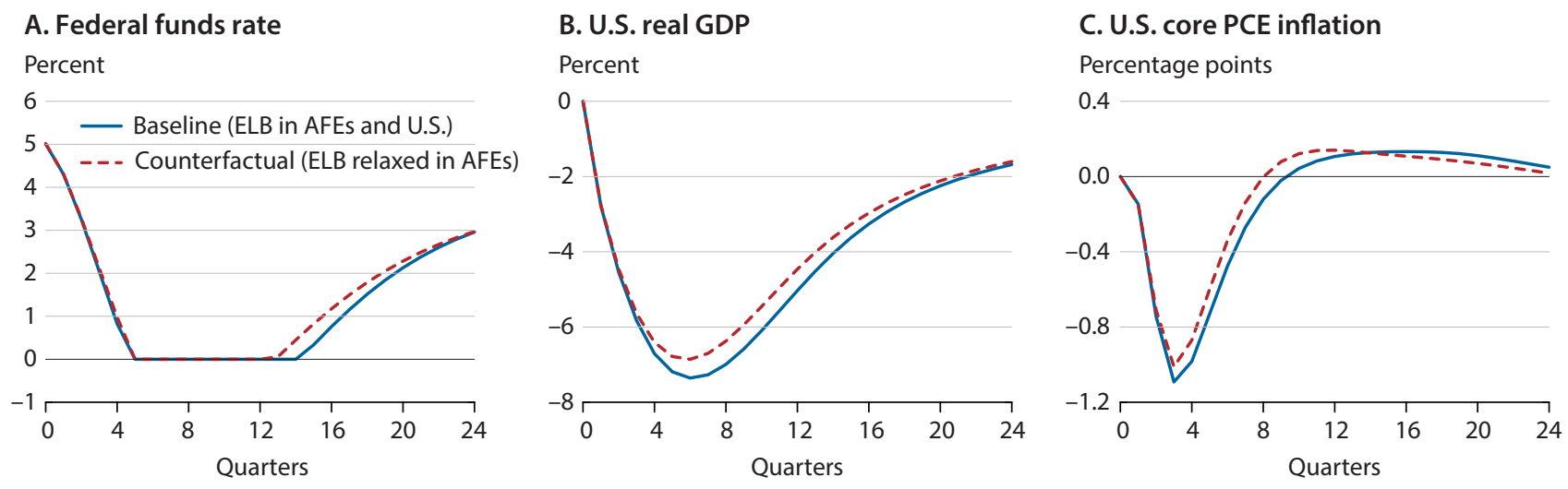

NOTE: We construct the recession scenario in the Sigma model (from Erceg, Guerrieri, and Gust, 2005) using a sequence of shocks to aggregate demand, financial conditions, and the exchange rate to match key features of the data during the GFC. In particular, we match selected targets that describe the experiences of AFEs and the United States during the GFC. We assume that the simulation starts with the federal funds rate at 5 percent and the policy rate in AFEs at 3.5 percent. U.S. real GDP and core inflation are shown in deviations from their steady-state values. To calibrate the size and timing of the shocks, we used the following targets: a trough in real GDP and core inflation in AFEs and the United States in line with the experience of the GFC; 15 percent appreciation of the real broad dollar; and a 320-basis-point increase in corporate spreads in AFEs and on the sequence of shocks. We then compute the path of the variables that would have been observed had the ELB not constrained the short rate in AFEs.

SOURCE: Authors' calculations.

Third, half-hearted commitments, or the perception that a central bank would tolerate persistent deviations from its objectives, can undermine the efficacy of both current and future policy actions. For example, the ECB's open-ended asset purchases since 2014 have been seen as more potent than its earlier long-term refinancing operations, perhaps because openended purchases and the associated large balance sheet expansion convey a clearer commitment to maintaining accommodative conditions for an extended period. $\underline{40}$ ECB president Mario Draghi's remarks in July 2012, that the institution was ready to do whatever it took to preserve the euro immediately and persistently, calmed financial markets because they conveyed a credible commitment-even though he provided no policy details (Draghi, 2012). As previously noted, the BOJ's timid use of FG and BSPs in the 1990s and 2000s may have undermined the credibility of the post-2013 policies in support of the 2 percent inflation target.

Finally, limited space to cut policy rates abroad, along with the challenges of deploying untested tools, likely left foreign economies more exposed to the GFC and created negative spillovers for the United States. For instance, the BOJ entered the GFC with its policy rate barely above its ELB, which may have exacerbated Japan's slump and created the need for greater reliance on BSPs and other tools. Figure 9 illustrates simulated paths of U.S. macro variables in a GFC-like scenario in which the ELB constrains both U.S. and AFE policy rates (labeled "Baseline") and a counterfactual scenario that relaxes the ELB in AFEs. $\frac{41}{}$ Our simu- 
lations suggest that the ELB on AFE policy rates depressed U.S. real GDP as much as 0.6 percent, lowered U.S. core inflation by as much as 0.15 percentage point, and delayed U.S. liftoff from the ELB by one quarter. $\underline{42}$

\section{CONCLUSION}

The FOMC has operated in a challenging environment from the GFC through 2019. The financial crisis produced a sharp rise in unemployment, and inflation persistently fell short of 2 percent during the post-GFC recovery and subsequent economic expansion. Structural transformations that could not be quickly recognized likely weakened the transmission channels of monetary policy and revealed the labor market gap to be larger than previously thought. With the ELB constraining the federal funds rate, the FOMC employed two novel tools, BSPs and FG, to further provide accommodation. These tools effectively facilitated the return to full employment and helped mitigate the ELB, though inflation ran somewhat below 2 percent prior to the onset of the pandemic. With the benefit of hindsight, even bolder use of these tools to achieve mandated goals seems feasible in the future and might have been helpful in the past. However, the experiences of the $\mathrm{BOJ}$ and ECB suggest that more-forceful deployment of these tools might still fail to return longer-run inflation expectations to target once they have slipped. Instead, these international episodes point to the importance of prompt action with a clear and sustained commitment. 


\section{APPENDIX A}

\section{Description of Counterfactual Policy Rate Simulations}

This appendix describes how we compute the counterfactual historical policy rates and outcomes shown in Figure 5 in the article, under the assumption that policymakers strictly followed the prescriptions of either the Taylor (1993) rule, the balanced-approach rule, or an inertial version of the balanced-approach rule. Table A1 describes the rules.

\section{Table A1}

\section{Simple Rules}

\begin{tabular}{ll}
\hline Taylor (1993) rule & $R_{t}=r_{t}^{L R}+\pi_{t}+0.5\left(\pi_{t}-\pi^{L R}\right)-$ ugap $_{t}$ \\
\hline Balanced-approach rule & $R_{t}=r_{t}^{L R}+\pi_{t}+0.5\left(\pi_{t}-\pi^{L R}\right)-2 u g a p_{t}$ \\
\hline Inertial balanced-approach rule & $R_{t}=0.85 R_{t-1}+0.15\left(r_{t}^{L R}+\pi_{t}+0.5\left(\pi_{t}-\pi^{L R}\right)-2 u g a p_{t}\right)$ \\
\hline
\end{tabular}

Consistent with the FOMC's annual “Statement on Longer-Run Goals and Monetary Policy Strategy" (FOMC, 2021), we set the inflation goal $\left(\pi^{L R}\right)$ to 2 percent. As intercept of the rules $\left(r_{t}^{L R}\right)$, we use the median SEP projection for the real federal funds rate in the longer run. For the unemployment gap $\left(\right.$ ugap $\left._{t}\right)$, we use the percentage-point deviation of the unemployment rate from the median longer-run estimate in the SEP.

We perform the simulations using an approach broadly similar to that described by Kashkari (2017). For all simulations, we use the data and model equations in the public release of the FRB/US model that are consistent with the March 2019 SEP. We assume that agents form VAR-based expectations so that they do not anticipate events such as the European sovereign debt crisis. For each simple rule, we begin by calculating the equation residuals of the model such that it perfectly replicates the historical data. Next, we iteratively calculate the model's counterfactual solution under each rule, zeroing out the residuals in the monetary policy rule equation. This procedure ensures that monetary policy strictly follows the assumed policy rule, while all other shocks in the model are held constant. It also means that the effects of the Federal Reserve's BSPs and FG are subsumed in the equation residuals and thus held constant across all simulations. 


\section{APPENDIX B}

\section{Description of Mandates and Strategies of the Bank of Japan, European Central Bank, and Bank of England}

This appendix describes the current monetary policy frameworks of the BOJ, ECB, and BOE. Unlike the Federal Reserve, these central banks' mandates define price stability as their primary objective. However, like the Federal Reserve, these central banks have pursued flexible inflation-targeting strategies in practice (Bernanke, 2003). Moreover, in responding to the GFC and other shocks, these central banks have also used BSPs and FG (as well as a number of other tools that we will describe). Appendix C provides a chronology of these central banks' policy actions since the GFC.

Bank of Japan. In 1997, the Japanese government significantly increased the BOJ's independence and established its price-stability objective, which the BOJ defined as a situation in which inflation rates do not affect economic decisions. In February 2012, the BOJ clarified that its price-stability goal meant aiming for annual inflation "within a positive range of 2 percent or lower" and set a goal of " 1 percent for the time being" (BOJ, 2012). In January 2013, the Japanese government and $\mathrm{BOJ}$ jointly announced a 2 percent consumer price index inflation target.

In the 1990s, the BOJ fought low inflation through low policy rates. In April 1999, it introduced its zero interest rate policy, which was supported by new FG, and, in 2001, launched its first quantitative easing (QE) program, purchasing short-term securities; these measures continued until 2006. Following the GFC, the BOJ launched a comprehensive monetary easing (CME) strategy in 2010 that included FG and a loan support program. The BOJ redoubled its anti-deflationary efforts in early 2013 with the adoption of its 2 percent inflation target and the announcement of a package of stimulative measures called quantitative and qualitative monetary easing (QQME). This package included large-scale, open-ended purchases of Japanese government bonds (JGBs), exchange-traded funds (ETFs), and Japanese real estate investment trusts (JREITs). These purchases expanded the BOJ's balance sheet to a much larger extent than its previous BSPs. In 2016, the BOJ expanded its QQME strategy further, introduced negative interest rate policies (NIRPs), and soon after added yield curve control (YCC). Under YCC, the BOJ explicitly targets both short- and long-term interest rates, setting the overnight deposit rate at negative 0.1 percent and conducting asset purchases to target a yield on 10-year JGBs at around zero percent.

European Central Bank. The Treaty on the Functioning of the European Union establishes price stability as the primary objective of Eurosystem monetary policy. It also provides that the ECB should avoid excessive fluctuations in employment and output as it pursues price stability. In 1998, the ECB's Governing Council defined price stability "as a year-on-year increase in the Harmonized Index of Consumer Prices for the euro area of below 2\%" (ECB, 1998). In 2003, the ECB's Governing Council clarified that it seeks to maintain inflation rates below, but close to, 2 percent over the medium term.

In response to the GFC, the ECB lowered the rate on its main refinancing operations to a bit above 0 percent (see Figure 7 in the article), conducted longer-term refinancing operations 


\section{Caldara, Gagnon, Martínez-García, Neely}

(LTROs) of 3-and 6-month maturities, and eventually complemented these measures with the first covered bond purchase programme (CBPP1) in 2009 and the Securities Market Programme (SMP) in 2010. The resulting expansion of the ECB's balance sheet was more modest than that of the Federal Reserve's or the BOE's at the time. As economic conditions improved, the ECB raised its policy rate in 2011 while keeping BSPs in place, but it then reversed course before the end of the year with the onset of the European sovereign debt crisis. The crisis led the ECB to deploy further accommodative measures. The ECB lengthened the maturity of its LTROs up to three years and launched a new round of the CBPP (CBPP2) in November 2011. President Draghi's "whatever it takes" remarks in July 2012, which had a calming effect on financial markets, foreshadowed the introduction of qualitative FG and further BSPsnotably the replacement of the SMP with the Outright Monetary Transactions Programme (OMTP) in September 2012 (Draghi, 2012). Despite these measures, the ECB's balance sheet expansion was temporary in nature-particularly from LTROs-and shrank by 2014 to its 2009-11 levels as banks made early repayments and financial conditions started to ease.

By mid-2014, the ECB's third phase started to reverse course and the ECB began to expand its balance sheet again: It made a first round of targeted LTROs (TLTRO I) in June 2014, launched a new round of its CBPP (CBPP3) in October 2014, and added its asset-backed securities purchase programme (ABSPP) in September 2014 and its public sector purchase programme (PSPP) in January 2015. In June 2014, the ECB introduced negative interest rates, and, in 2016, lowred the deposit rate to -0.4 percent. The ECB further strengthened its BSP actions later on with another round of TLTROs (TLTRO II) in March 2016, the introduction of its corporate sector purchase programme (CSPP) in June 2016, and an emergency liquidity assistance facility in June 2017. An additional round of TLTROs (TLTRO III) was announced in June 2019. As of mid-2019, the size of the ECB's balance sheet stood at around 40 percent of euro area GDP, a footprint about twice as large as the Federal Reserve's (see Figure 7 in the article).

Bank of England. The BOE seeks to achieve consumer price index inflation at the annual rate of 2 percent. In response to the GFC, the BOE cut its main policy rate from 5.75 percent to an ELB of 0.5 percent. In March 2009, it embarked on the first of three LSAP phases. Its purchases totaled $£ 200$ billion and comprised mostly gilts, along with residual amounts of commercial paper and corporate bonds to support private debt issuance. In response to the European sovereign debt crisis, the BOE launched a second phase of LSAPs in October 2011, introduced a funding for lending scheme in 2012, and used threshold-based FG. In August 2016, following the Brexit referendum, the BOE cut its policy rate to 0.25 percent, announced a third phase of asset purchases, and enhanced its liquidity provision. 


\section{APPENDIX C}

Summary of Policy Actions and Communications in Selected Major Advanced Economies at the Effective Lower Bound

\section{Panel A: Balance sheet policies}

\begin{tabular}{|c|c|c|c|}
\hline Federal Reserve & Bank of Japan & European Central Bank & Bank of England \\
\hline LSAP & $C M E^{*}$ & LTRO & APF: Gilt (QE1) \\
\hline LSAP1: November 2008 to March 2010 & October 2010 to March 2013 & 3 months: Starting in August 2007 & January 2009 to February 2010 \\
\hline LSAP2: November 2010 to June 2011 & QQME (JGB purchases) & 6 months: March 2008 to May 2010 & APF: Commercial paper \\
\hline LSAP3: September 2012 to October 2014 & April 2013 to present & 12 months: June 2009 to October 2011 & March 2009 to November 2011 \\
\hline Maturity Extension Program (MEP) & QQME (ETFs and JREIT purchases) & CBPP1 & APF: Secured commercial paper and \\
\hline \multirow[t]{22}{*}{ September 2011 to June 2012} & April 2013 to present & July 2009 to June 2010 & corporate bond secondary market scheme \\
\hline & & $S M P$ & March 2009 to August 2016 \\
\hline & & May 2010 to September $2012^{\dagger}$ & APF: Gilt (QE2) \\
\hline & & CBPP2 & October 2011 to October 2012 \\
\hline & & November 2011 to October 2012 & APF: Gilt (QE3) \\
\hline & & LTRO & August 2016 to present \\
\hline & & 3 years: In December 2011 and March 2012 & APF: Corporate bond purchase scheme \\
\hline & & OMTP & September 2016 to April 2017 \\
\hline & & September 2012 to present ${ }^{\dagger}$ & \\
\hline & & TLTRO & \\
\hline & & TLTRO I: June 2014 to present & \\
\hline & & ABSPP & \\
\hline & & September 2014 to December $2018^{\ddagger}$ & \\
\hline & & CBPP3 & \\
\hline & & October 2014 to December $2018^{\ddagger}$ & \\
\hline & & PSPP & \\
\hline & & January 2015 to present & \\
\hline & & CSPP & \\
\hline & & June 2016 to December $2018^{\ddagger}$ & \\
\hline & & TLTRO & \\
\hline & & TLTRO II: March 2016 to present & \\
\hline & & TLTRO III: September 2019 to present & \\
\hline
\end{tabular}




\section{APPENDIX C, cont'd}

Summary of Policy Actions and Communications in Selected Major Advanced Economies at the Effective Lower Bound

Panel B: Forward guidance: Qualitative, calendar-based, and threshold-based

Type of FG
Qualitative

Calendar-based

Threshold-based
Federal Reserve December 2008 to July $2011^{\S}$ August 2011 to November 2012*

December 2012 to February 2014

\begin{tabular}{c} 
Bank of Japan \\
\hline With QE \\
\hline March 2001 to March 2006 \\
\hline With CME \\
\hline $\begin{array}{c}\text { October } 2010 \text { to March } 2013 \\
\text { With QQME with price-stability } \\
\text { target of } 2 \text { percent }{ }^{\text {I }}\end{array}$ \\
\hline April 2013 to present
\end{tabular}

$\frac{\text { European Central Bank }}{\text { July } 2013 \text { to present }}{ }^{\dagger}$

October 2014 to early $2015^{\dagger}$

Early 2015 to present ${ }^{\dagger}$
Bank of England

Early 2015 to present ${ }^{*}$

August 2013 to early $2015^{* *}$

\section{Panel C: Negative interest rates}

\begin{tabular}{|c|c|c|c|c|}
\hline Type of negative rates & Federal Reserve & Bank of Japan & European Central Bank & Bank of England \\
\hline \multirow[t]{2}{*}{ Short rates } & & QQME with NIRP & Negative deposit facility rate & \\
\hline & & January 2016 to August 2016 & June 2014 to present & \\
\hline \multirow[t]{2}{*}{ Short and long rates } & & QQME with YCC \# & & \\
\hline & & September 2016 to present & & \\
\hline
\end{tabular}

NOTE: ${ }^{*}$ The Federal Reserve's communication practices evolved significantly with the introduction, in January 2012, of an explicit inflation target of 2 percent on headline PCE inflation and of a depiction of the FOMC's assumptions for the federal funds rate (informally known as the "dot plot") in the SEP.

† President Draghi's "whatever it takes" remarks on July 26, 2012, preceded the formal implementation of FG and the deployment of the OMTP (Draghi, 2012). The ECB's SMP was discontinued at the same time as that program was introduced, which would then allow purchases ("outright transactions") in secondary, sovereign bond markets, under certain conditions, of bonds issued by euro area member states.

₹ The ECB stopped net purchases in January 2019 but continued to reinvest the principal payments from maturing securities held in the ABSPP, CBPP3, and CSPP portfolios.

$\S$ The Federal Reserve used qualitative FG before the GFC during the "deflation scare" episode (August 2003 to December 2005).

"Another policy tool considered by the BOJ is raising the inflation target-Japanese policymakers did this while implementing QQME with a 2 percent price stability target in April

2013 (up from a midpoint of 1 percent set a year earlier, and a goal of positive inflation before that).

\# The BOJ introduced YCC to enhance its QQME with the NIRP program.

** The BOE committed not to raise rates until the unemployment rate fell to 7 percent, which happened sooner than expected. It then revamped its FG strategy in February 2014 , promising to focus on 18 measures of spare capacity instead, but it stopped mentioning threshold-based FG in its quarterly economic updates by early 2015 . The BOE has continued to use qualitative FG to signal the path of interest rates but only incidentally. 


\section{APPENDIX D}

\section{Selected Studies of Financial Market Effects of Balance Sheet Policies and Forward Guidance}

\begin{tabular}{|c|c|}
\hline Gagnon et al. (2011) & $\begin{array}{l}\text { 10-year Treasury yield fell } 91 \text { basis points over baseline } \\
\text { event set and } 55 \text { basis points over the "all-event" set. }\end{array}$ \\
\hline Lo Duca, Nicoletti, and Martinez (2016) & $\begin{array}{l}\text { Yield declines stimulated bond issuance, especially in } \\
\text { emerging markets. }\end{array}$ \\
\hline D'Amico and King (2013) & Asset purchases produce local supply effects. \\
\hline Di Maggio, Kermani, and Palmer (2020) & $\begin{array}{l}\text { MBS purchases, but not Treasury purchases, depressed } \\
\text { mortgage rates with particularly strong effects on conform- } \\
\text { ing mortgages. }\end{array}$ \\
\hline Rodnyansky and Darmouni (2017) & $\begin{array}{l}\text { Institutions with relatively large holdings of MBS expanded } \\
\text { lending after LSAP1 and LSAP3, but not after LSAP2. }\end{array}$ \\
\hline Kurtzman, Luck, and Zimmermann (2018) & $\begin{array}{l}\text { Banks with greater MBS holdings reduced lending standards } \\
\text { and made riskier loans. }\end{array}$ \\
\hline Chakraborty, Goldstein, and MacKinlay (2020) & $\begin{array}{l}\text { Banks that owned greater amounts of MBS increased } \\
\text { mortgage lending at the expense of commercial and } \\
\text { industrial lending. }\end{array}$ \\
\hline Neely (2015) & $\begin{array}{l}\text { BSPs spilled over to foreign exchange markets and foreign } \\
\text { bond markets, reducing the value of the dollar and foreign } \\
\text { bond yields. }\end{array}$ \\
\hline Kiley (2014) & $\begin{array}{l}\text { BSPs had modest effects on equities because they moved } \\
\text { the medium and long yields but not short yields. }\end{array}$ \\
\hline Hamilton and Wu (2012) & $\begin{array}{l}\text { A segmented-markets model implies that a } \$ 400 \text { billion } \\
\text { purchase will reduce } 10 \text {-year Treasury yields by } 13 \text { basis } \\
\text { points. }\end{array}$ \\
\hline Greenwood and Vayanos (2014) & $\begin{array}{l}\text { Maturity-weighted debt-to-GDP increases long-term yields. } \\
\text { The Federal Reserve's LSAP1 and LSAP } 2 \text { together reduced } \\
\text { yields } 40 \text { basis points. }\end{array}$ \\
\hline Altavilla and Giannone (2017) & $\begin{array}{l}\text { The unconventional policy effects on the Federal Reserve } \\
\text { Bank of Philadelphia's SPF forecasts are persistent and } \\
\text { consistent with those from event studies. }\end{array}$ \\
\hline Greenwood et al. (2014) & $\begin{array}{l}\text { U.S. Treasury lengthening the maturity structure of U.S. } \\
\text { debt may have offset one-third of the effects of Federal } \\
\text { Reserve asset purchases on long yields. }\end{array}$ \\
\hline Raskin (2013) & $\begin{array}{l}\text { The FOMC's promise to keep rates low until mid- } 2013 \text { had } \\
\text { a much bigger effect than the promise to keep rates low } \\
\text { until mid-2014. }\end{array}$ \\
\hline Femia, Friedman, and Sack (2013) & $\begin{array}{l}\text { The Federal Reserve Bank of New York's Survey of Primary } \\
\text { Dealers indicates that FG provides market participants with } \\
\text { economic information. }\end{array}$ \\
\hline
\end{tabular}




\section{Caldara, Gagnon, Martínez-García, Neely}

\section{NOTES}

1 The SEP added the central tendency and range of longer-run estimates for the unemployment rate, headline PCE inflation, and real gross domestic product (GDP) growth in April 2009, and corresponding median estimates in September 2015. Before the latter date, we derive median estimates from declassified individual SEP contributions where possible and report the midpoint of the central tendency otherwise.

$\underline{2}$ These statistics are based on the peak-to-NAIRU analysis of Eberly, Stock, and Wright (2020). Comparisons across recoveries are sensitive to the reference period. For example, the unemployment rate rose modestly in the first two years of the 1990s and early 2000s economic expansions, making the labor market recovery from the GFC look especially strong relative to those episodes when measured from the start of the economic expansion rather than from the peak in the unemployment rate. By contrast, the unemployment rate fell 3.5 percentage points in the first year and a half following the 1981-82 recession, making the initial labor market recovery from the GFC look especially weak relative to that episode.

3 More precisely, the labor force participation rate held steady, on net, from late 2013 until 2019, in contrast with the trend decline projected by Aaronson et al. (2014).

4 For evidence on the role of longer-run inflation expectations and slack in determining realized inflation, see Ball and Mazumder (2011); Del Negro, Giannoni, and Schorfheide (2015); Duncan and Martínez-García (2015); Coibion and Gorodnichenko (2015); Yellen (2015); and Kabukcuoglu and Martínez-García (2018).

5 As of the writing of this article, 2014 is the latest calendar year for which Tealbook forecasts and FOMC memos are publicly available. In mid-2014, the staff also projected longer-run inflation expectations to eventually drift higher, pushing underlying inflation toward 2 percent, but acknowledged that such an upward drift was highly uncertain.

6 See, for example, Aaronson et al. (2015) and Cairó and Cajner (2018).

7 To some extent, a step-down in productivity growth following the information technology boom of the mid-1990s to early 2000 s is unsurprising, though the extent and timing of that step-down were difficult to predict. See Fernald (2015) and Gordon (2015).

$\underline{8}$ All estimates but one in Figure 2 are "one sided," meaning that, at each date, they use historical data only up to that date. Accordingly, the fact that many series show a decline around the GFC need not imply that $r^{*}$ itself fell as a result of the crisis, but rather that the crisis marked the moment when models began to identify the fall.

9 For evidence suggesting such a change in monetary policy, see Clarida, Galí, and Gertler (2000); Boivin and Giannoni (2006); and Boivin, Kiley, and Mishkin (2010).

10 Based on pre-2020 information, Figure 4 reports, for the first quarter of each calendar year, median SEP projections at various yearly horizons, along with corresponding medium-term projections from market participants. Individual SEP projections are conditional on each policymaker's assessment of appropriate monetary policy, whereas market participants' projections are modal forecasts. For this reason, the two projection concepts reported in Figure 3 differ. Evidence of policymakers' slow recognition of the fall in productivity growth is corroborated by the significant downward revisions to real output growth in the longer run: The median SEP estimate fell from 2.6 percent in April 2009 to 1.9 percent by mid-2019.

11 Policymakers expected inflation to be weaker than did market participants during the first years of the recovery, even though policymakers held relatively upbeat views of future real GDP growth and unemployment. This observation is consistent with policymakers assuming that the necessary reduction in slack to lift inflation was larger than market participants expected. We also note that policymakers' inflation forecast errors averaged about zero, even though the unemployment rate fell faster than policymakers had anticipated, suggesting that inflation proved even less responsive to movements in slack than policymakers had assumed.

12 Burke et al. (2010) review the considerations raised by Board staff at the time.

13 The FOMC's use of BSPs and FG in response to the GFC was unprecedented. Though the FOMC purchased longerterm Treasury securities using proceeds from sales of shorter-term holdings in the early 1960s (the so-called Operation Twist), the total size of this program, at 1.7 percent of GDP, was much smaller than total purchases during the GFC and its aftermath (Swanson, 2011). Also, before the GFC, the FOMC used FG regarding the likely path of interest rates on occasion, but that guidance was usually confined to a relatively short time frame. 
14 FG can serve dual purposes: It can convey policymakers' predictions about future economic conditions and policies or their commitment to future policy. These two purposes are called "Delphic" and "Odyssean," respectively, by Campbell et al. (2017). Del Negro, Giannoni, and Schorfheide (2015) argue that the FOMC's FG became more of an Odyssean commitment to stimulative policies with the introduction of the 2 percent inflation target and the release of FOMC participants' assessments of appropriate monetary policy in 2012.

15 The mean DSGE estimates in Gust et al. (2017) suggest that a binding ELB accounted for about 30 percent (roughly 2 percentage points) of the 6 percent contraction in GDP in 2009 relative to its peak in 2007 and was responsible for an even larger fraction of the ensuing slow recovery. The estimates of Gust et al. (2017), which embed the effects of FG and LSAP, are more consistent with the more immediate negative effects of the ELB on outcomes than are those of Eberly, Stock, and Wright (2020).

16 See, for example, Swanson (2018); Sims and Wu (2019); and Debortoli, Galí, and Gambetti (2020).

17 For example, Cabana et al. (2008) estimate that "a purchase of $\$ 50$ billion of longer-term Treasury securities... would lower the 10-year Treasury yield somewhere between 2 and 10 basis points." See also Gagnon and Holscher (2008) and Erceg, Kiley, and Levin (2008a,b).

18 The novelty of LSAP1 meant that FOMC announcements were presumably the main source of information about the program, so researchers have used the reactions to LSAP1 announcements to estimate the total effect of the program. This was not possible for later programs, because a much wider set of news presumably affected market expectations.

19 One exception is Greenlaw et al. (2018), who take a skeptical view of the effects of Federal Reserve's asset purchases. Bhattarai and Neely (forthcoming) and Kuttner (2018) review research on BSPs and FG.

$\underline{20}$ See Di Maggio, Kermani, and Palmer (2020).

$\underline{21}$ See Rodnyansky and Darmouni (2017); Chakraborty, Goldstein, and MacKinlay (2020); and Kurtzman, Luck, and Zimmermann (2018).

$\underline{22}$ See Swanson and Williams (2014).

$\underline{23}$ Using data from 2007 to mid-2014, Greenwood et al. (2014) report that the Federal Reserve's BSP programs reduced the publicly held 10-year equivalent universe (Treasury securities, MBS, and agencies) by approximately 15.6 percent of GDP, while Treasury maturity extensions increased the outstanding 10-year equivalents by 5.5 percent of GDP. Greenwood et al. (2014) then calculate that the Treasury's duration increase offset more than 35 percent $(\approx 5.5 / 15.6$ ) of the effect of the Federal Reserve's BSP and FG policies on 10-year yields. Greenwood et al. (2014) cite meta estimates from Williams (2014) to put the total effect of Federal Reserve policies on 10-year yields at 137 basis points, so the offset was 48 basis points.

24 Swanson (2021) calculates that the point estimate of the half-life of FG effects is 6.5 months, which is statistically indistinguishable from complete persistence.

$\underline{25} \mathrm{See}$, for example, the minutes to the September 2012 FOMC meeting, available on the Federal Reserve Board's website at https://www.federalreserve.gov/monetarypolicy/files/fomcminutes20120913.pdf.

$\underline{26}$ See Gilchrist and Zakrajšek (2013).

$\underline{27}$ See Kiley (2018) and Chung et al. (2019) for stochastic simulations of the U.S. economy under an endogenous balance sheet response.

28 Clarida (2019a) discusses the Federal Reserve's monetary policy framework articulated in 2012 and the scope of the Federal Reserve's 2019-2020 review of its strategy, tools, and communication practices.

$\underline{29}$ Taylor (1993) shows that the rule now bearing his name fits policy rate settings well during the 1987-92 period. See Yellen (2017) for an application of the balanced-approach rule. The inertial version of the balanced-approach rule has been featured in Federal Reserve Board staff analysis; see, for example, Erceg et al. (2012).

30 The median SEP projection for core inflation three years out was only 1.8 percent when the FOMC announced its 2 percent objective in 2012. The simulations in Engen, Laubach, and Reifschneider (2015) and Chung et al. (2019) suggest that policymakers would have needed to boost asset purchases an extra couple trillion dollars to meet their inflation objective over the medium term. 


\section{Caldara, Gagnon, Martínez-García, Neely}

31 Although headline inflation exceeded the targets in Japan and the euro area on occasion, that achievement typically reflected temporary factors, for example, the effects of the 2014 value-added tax, or VAT, hike in Japan and of global oil price rebounds in the euro area.

32 Appendix $B$ describes the policy frameworks of the $B O J, E C B$, and $B O E ;$ Appendix $C$ summarizes their key policy actions and communications in the wake of the GFC.

33 Some policy tools used by the ECB and BOJ_such as negative policy rates and yield curve control—are not part of the FOMC's current framework.

$\underline{34}$ For a review of financial and macroeconomic effects in the United States and abroad, see Andrade et al. (2016); Lombardi, Siklos, and St. Amand (2018); Kuttner (2018); and Dell'Ariccia, Rabanal, and Sandri (2018), who focus on the effect on yields and bank lending. On the international experience and spillovers, see Clarida (2019b), MartínezGarcía (2019), and the evidence in Haldane et al. (2016), Chen et al. (2016), and Martínez-García (2018).

35 See Carvalho and Ferrero (2013) on the BOJ's slow acknowledgment of the fall in $r^{*}$ and Correa and Davies (2008) on the monetary policy implications of Japanese banking-sector weaknesses.

$\underline{36}$ Japanese asset purchases during this period were probably unsuccessful partly because the BOJ purchased bonds with relatively short remaining maturity (McCauley and Ueda, 2009). The average maturity of the BOJ's portfolio actually declined from 2001 to 2005.

37 See Krugman (1998); Benhabib, Schmitt-Grohé, and Uribe (2011); Eggertsson (2010); and Bullard (2010) for a discussion of self-fulfilling deflationary expectations and policy options in a liquidity trap (when policy rates are constrained at the ELB).

38 See Shirakawa (2012) and Kuroda (2019).

39 Hesse, Hofmann, and Weber (2018) revisit the macroeconomic and financial effects of the asset purchase programs launched by the Federal Reserve and the BOE from 2008 and suggest that the early programs "had significant positive macroeconomic effects, while those of the subsequent ones were weaker and in part not significantly different from zero." See also Joyce and Tong (2012) and Churm et al. (2021).

40 See Andrade et al. (2016); Doehr and Martínez-García (2015); and Weale and Wieladek (2016) for a related discussion of the macroeconomic effects of news and announcements about asset purchase programs in the United States and the United Kingdom.

41 We use a three-country version of SIGMA, a DSGE model maintained by Federal Reserve Board staff. In this simulation, AFE policymakers cut their policy rate 350 basis points at the recession's onset.

$\underline{42}$ In the current low interest rate environment, the ELB would bind faster in the AFEs for a given recessionary shock than in our scenario, leading to larger downturns abroad and greater negative spillovers for the U.S. economy, unless AFE central banks provide accommodation through other tools.

\section{REFERENCES}

Aaronson, Daniel; Hu, Luojia; Seifoddini, Arian and Sullivan, Daniel G. "Changing Labor Force Composition and the Natural Rate of Unemployment." Chicago Fed Letter 338, Federal Reserve Bank of Chicago, 2015; https://www.chicagofed.org/publications/chicago-fed-letter/2015/338.

Aaronson, Stephanie; Cajner, Tomaz; Fallick, Bruce; Galbis-Reig, Felix; Smith, Christopher and Wascher, William. "Labor Force Participation: Recent Developments and Future Prospects." Brookings Papers on Economic Activity, Fall 2014, pp. 197-275; https://doi.org/10.1353/eca.2014.0015.

Altavilla, Carlo and Giannone, Domenico. "The Effectiveness of Non-Standard Monetary Policy Measures: Evidence from Survey Data." Journal of Applied Econometrics, August 2017, 32(5), pp. 952-64; https://doi.org/10.1002/jae.2559.

Andrade, Philippe; Breckenfelder, Johannes H.; De Fiore, Fiorella; Karadi, Peter and Tristani, Oreste. “The ECB's Asset Purchase Programme: An Early Assessment." ECB Discussion Paper 1956, European Central Bank, September 2016; https://www.ecb.europa.eu//pub/pdf/scpwps/ecbwp1956.en.pdf.

Ball, Laurence and Sandeep, Mazumder. "Inflation Dynamics and the Great Recession." Brookings Papers on Economic Activity, Spring 2011, pp. 337-405; https://doi.org/10.1353/eca.2011.0005. 
Bank of Japan. "The Price Stability Goal in the Medium to Long Term." Press Release, February 14, 2012; https://www.boj.or.jp/en/announcements/release_2012/k120214b.pdf.

Baumeister, Christiane and Benati, Luca. "Unconventional Monetary Policy and the Great Recession: Estimating the Macroeconomic Effects of a Spread Compression at the Zero Lower Bound." International Journal of Central Banking, June 2013, 9, pp. 165-212; https://www.ijcb.org/journal/ijcb13q2a9.pdf.

Benhabib, Jess; Schmitt-Grohé, Stephanie and Uribe, Martín. "Monetary Policy and Multiple Equilibria." American Economic Review, March 2011, 91, pp. 167-86; https://doi.org/10.1257/aer.91.1.167.

Bernanke, Ben S. "A Perspective on Inflation Targeting." Speech to the Annual Washington Policy Conference of the National Association of Business Economists, Washington, DC, March 25, 2003; https://www.federalreserve.gov/boarddocs/speeches/2003/20030325/default.htm.

Bhattarai, Saroj and Neely, Christopher J. "An Analysis of the Literature on International Unconventional Monetary Policy." Journal of Economic Literature (forthcoming).

Boivin, Jean and Giannoni, Marc P. "Has Monetary Policy Become More Effective?" Review of Economics and Statistics, August 2006, 88, pp. 445-62; https://doi.org/10.1162/rest.88.3.445.

Boivin, Jean; Kiley, Michael T. and Mishkin, Frederic S. “How Has the Monetary Transmission Mechanism Evolved over Time?" in Benjamin M. Friedman and Michael Woodford, eds., Handbook of Monetary Economics. Volume 3. Elsevier, 2010, pp. 369-422; https://doi.org/10.1016/B978-0-444-53238-1.00008-9.

Bullard, James B. "Seven Faces of 'the Peril.'” Federal Reserve Bank of St. Louis Review, September/October 2010, 92(5), pp. 339-52; https://doi.org/10.20955/r.92.339-52.

Burke, Chris; Hilton, Spence; Judson, Ruth; Lewis, Kurt and Skeie, David. "Reducing the IOER Rate: An Analysis of Options." Memorandum to the Federal Open Market Committee, Federal Reserve Bank of New York, Board of Governors of the Federal Reserve System, Divisions of International Finance and Monetary Affairs, August 5, 2010; https://www.federalreserve.gov/monetarypolicy/files/FOMC20100805memo05.pdf.

Cabana, Mark; Forster, Jeremy; Frost, Josh; Gagnon, Joseph; Hilton, Spence; Rodrigues, Tony and Steinberg, Michelle. "Purchases of Longer-Term Treasury Securities." Memorandum to the Federal Open Market Committee, Federal Reserve Bank of New York, Board of Governors of the Federal Reserve System, Division of Monetary Affairs, December 5, 2008; https://www.federalreserve.gov/monetarypolicy/files/FOMC20081212memo16.pdf.

Cairó, Isabel and Cajner, Tomaz. "Human Capital and Unemployment Dynamics: Why More Educated Workers Enjoy Greater Employment Stability." Economic Journal, March 2018, 128, pp. 652-82; https://doi.org/10.1111/ecoj.12441.

Campbell, Jeffrey R.; Fisher, Jonas D.M.; Justiniano, Alejandro and Melosi, Leonardo. "Forward Guidance and Macroeconomic Outcomes since the Financial Crisis," in Martin Eichenbaum and Jonathan A. Parker, eds., NBER Macroeconomics Annual. Volume 31. National Bureau of Economic Research, 2017; https://doi.org/10.1086/690242.

Carvalho, Carlos and Ferrero, Andrea. "What Explains Japan's Persistent Deflation?" 2013 Meeting Paper 1163, Society for Economic Dynamics, 2013; https://economicdynamics.org/meetpapers/2013/paper_1163.pdf.

Chakraborty, Indraneel; Goldstein, Itay and MacKinlay, Andrew. "Monetary Stimulus and Bank Lending." Journal of Financial Economics, April 2020, 136(1), pp. 189-218; https://doi.org/10.1016/j.jfineco.2019.09.007.

Chen, Han; Cúrdia, Vasco and Ferrero, Andrea. "The Macroeconomic Effects of Large-Scale Asset Purchase Programs." Economic Journal, November 2012, 122, pp. F289-315; https://doi.org/10.1111/j.1468-0297.2012.02549.x.

Chen, Qianying; Filardo, Andrew; He, Dong and Zhu, Feng. "Financial Crisis, U.S. Unconventional Monetary Policy and International Spillovers." Journal of International Money and Finance, October 2016, 67, pp. 62-81; https://doi.org/10.1016/j.jimonfin.2015.06.011.

Chung, Hess; Gagnon, Etienne; Nakata, Taisuke; Paustian, Matthias; Schlusche, Bernd; Trevino, James; Vilán, Diego and Zheng, Wei. "Monetary Policy Options at the Effective Lower Bound: Assessing the Federal Reserve's Current Policy Toolkit." Finance and Economics Discussion Series 2019-003, Board of Governors of the Federal Reserve System, February 2019; https://doi.org/10.17016/FEDS.2019.003.

Churm, Rohan; Joyce, Michael; Kapetanios, George and Theodoridis, Konstantinos. "Unconventional Monetary Policies and the Macroeconomy: The Impact of the UK's QE2 and Funding for Lending Scheme." Quarterly Review of Economics and Finance, May 2021, 80, pp. 721-736; https://doi.org/10.1016/j.qref.2018.10.004. 


\section{Caldara, Gagnon, Martínez-García, Neely}

Clarida, Richard. "The Federal Reserve's Review of Its Monetary Policy Strategy, Tools, and Communication Practices." Speech to the 2019 U.S. Monetary Policy Forum, sponsored by the Initiative on Global Markets at the University of Chicago Booth School of Business, New York, NY, February 22, 2019a; https://www.federalreserve.gov/newsevents/speech/clarida20190222a.htm.

Clarida, Richard. "The Global Factor in Neutral Policy Rates: Some Implications for Exchange Rates, Monetary Policy, and Policy Coordination." International Finance, Spring 2019b, 22(1), pp. 2-19; https://doi.org/10.1111/infi.12345.

Clarida, Richard; Galí, Jordi and Gertler, Mark. "Monetary Policy Rules and Macroeconomic Stability: Evidence and Some Theory." Quarterly Journal of Economics, February 2000, 115, pp. 147-80; https://doi.org/10.1162/003355300554692.

Coibion, Olivier and Gorodnichenko, Yuriy. "Is the Phillips Curve Alive and Well after All? Inflation Expectations and the Missing Disinflation." American Economic Journal: Macroeconomics, January 2015, 7, pp. 197-232; https://doi.org/10.1257/mac.20130306.

Correa, Ricardo and Davies, Sally. "Implications of the Health of the Japanese Banking Sector for the Effectiveness of Monetary Policy." Memorandum to the Federal Open Market Committee, Board of Governors of the Federal Reserve System, Division of International Finance, December 5, 2008; https://www.federalreserve.gov/monetarypolicy/files/FOMC20081212memo06.pdf.

D'Amico, Stefania and King, Thomas B. "Flow and Stock Effects of Large-Scale Treasury Purchases: Evidence on the Importance of Local Supply." Journal of Financial Economics, May 2013, 108(2), pp. 425-48; https://doi.org/10.1016/j.jfineco.2012.11.007.

Debortoli, Davide; Galí, Jordi and Gambetti, Luca. "On the Empirical (Ir)Relevance of the Zero Lower Bound Constraint." NBER Macroeconomics Annual, 2020, 34, pp. 141-170; https://doi.org/10.1086/707177.

Dell'Ariccia, Giovanni; Rabanal, Pau and Sandri, Damiano. "Unconventional Monetary Policy in the Euro Area, Japan, and the United Kingdom." Journal of Economic Perspectives, Fall 2018, 32, pp. 147-72; https://doi.org/10.1257/jep.32.4.147.

Del Negro, Marco; Giannone, Domenico; Giannoi, Marc and Tambalotti, Andrea. "Global Trends in Interest Rates." Journal of International Economics, May 2019, 118, pp. 248-62; https://doi.org/10.1016/j.jinteco.2019.01.010.

Del Negro, Marco; Giannoni, Marc and Patterson, Christina. "The Forward Guidance Puzzle." Staff Report 574, Federal Reserve Bank of New York, October 2012 (revised December 2015); https://www.newyorkfed.org/research/staff reports/sr574.html.

Del Negro, Marco; Giannoni, Marc P. and Schorfheide, Frank. "Inflation in the Great Recession and New Keynesian Models." American Economic Journal: Macroeconomics, January 2015, 7, pp. 168-96; https://doi.org/10.1257/mac.20140097.

Di Maggio, Marco; Kermani, Amir and Palmer, Christopher. "How Quantitative Easing Works: Evidence on the Refinancing Channel." Review of Economic Studies, May 2020, 87(3), pp. 1498-528; https://doi.org/10.1093/restud/rdz060.

Doehr, Rachel and Martínez-García, Enrique. "Monetary Policy Expectations and Economic Fluctuations at the Zero Lower Bound." Globalization and Monetary Policy Institute Working Paper 240, Federal Reserve Bank of Dallas, May 2015; https://doi.org/10.24149/gwp240.

Draghi, Mario. "Remarks Made by Mario Draghi." Speech to the Global Investment Conference, London, England, July 26, 2012; https://www.ecb.europa.eu/press/key/date/2012/html/sp120726.en.html.

Duncan, Roberto and Martínez-García, Enrique. “Forecasting Local Inflation with Global Inflation: When Economic Theory Meets the Facts." Globalization and Monetary Policy Institute Working Paper 235, Federal Reserve Bank of Dallas, April 2015; https://doi.org/10.24149/gwp235.

Eberly, Janice C.; Stock, James H. and Wright, Jonathan H. "The Federal Reserve's Current Framework for Monetary Policy: A Review and Assessment." International Journal of Central Banking, February 2020, 16, pp. 5-71; https://www.ijcb.org/journal/ijcb2002 1.pdf.

Eggertsson, Gauti B. "Liquidity Trap," in Steven N. Durlauf and Lawrence E. Blume, eds., Monetary Economics. The New Palgrave Economics Collection. Palgrave Macmillan, 2010, pp. 137-45; https://doi.org/10.1057/9780230280854 18. 
Engen, Eric M.; Laubach, Thomas and Reifschneider, David. "The Macroeconomic Effects of the Federal Reserve's Unconventional Monetary Policies." Finance and Economics Discussion Series 2015-005, Board of Governors of the Federal Reserve System, February 2015; https://doi.org/10.17016/FEDS.2015.005.

Erceg, Christopher; Faust, Jon; Kiley, Michael; Laforte, Jean-Philippe; López-Salido, David; Meyer, Stephen; Nelson, Edward; Reifschneider, David and Tetlow, Robert. "An Overview of Simple Policy Rules and Their Use in Policymaking in Normal Times and Under Current Conditions." Memorandum to the Federal Open Market Committee, Board of Governors of the Federal Reserve System, Divisions of International Finance, Monetary Affairs, and Research and Statistics, July 18, 2012; https://www.federalreserve.gov/monetarypolicy/files/FOMC20120718memo02.pdf.

Erceg, Christopher J.; Guerrieri, Luca and Gust, Christopher. "SIGMA: A New Open Economy Model for Policy Analysis." International Finance Discussion Paper Number 835, Board of Governors of the Federal Reserve System, July 2005; https://www.federalreserve.gov/pubs/ifdp/2005/835/revision/ifdp835r.htm.

Erceg, Christopher; Kiley, Michael and Levin, Andrew. "Quantitative Analysis of Policy Alternatives Using the FRB/ US Model." Memorandum to the Federal Open Market Committee, Board of Governors of the Federal Reserve System, Divisions of International Finance, Research and Statistics, and Monetary Affairs, December 5, 2008a; https://www.federalreserve.gov/monetarypolicy/files/FOMC20081212memo21.pdf.

Erceg, Christopher; Kiley, Michael and Levin, Andrew. "Communication and Commitment Strategies at Very Low Interest Rates." Memorandum to the Federal Open Market Committee, Board of Governors of the Federal Reserve System, Divisions of International Finance, Research and Statistics, and Monetary Affairs, December 5, 2008b; https://www.federalreserve.gov/monetarypolicy/files/FOMC20081212memo20.pdf.

European Central Bank. "A Stability-Oriented Monetary Policy Strategy for the ESCB." Press Release, October 13, 1998; https://www.ecb.europa.eu/press/pr/date/1998/html/pr981013 1.en.html.

Federal Open Market Committee. "Statement of Longer-Run Goals and Monetary Policy Strategy." Adopted effective January 24, 2012; as reaffirmed effective January 26, 2021; https://www.federalreserve.gov/monetarypolicy/files/FOMC LongerRunGoals.pdf.

Federal Open Market Committee. FOMC Statement, September 2012; https://www.federalreserve.gov/newsevents/pressreleases/monetary20120913a.htm.

Federal Open Market Committee. FOMC Statement, August 2011; https://www.federalreserve.gov/newsevents/pressreleases/monetary20110809a.htm.

Femia, Katherine; Friedman, Steven and Sack, Brian P. "The Effects of Policy Guidance on Perceptions of the Fed's Reaction Function." Staff Report 652, Federal Reserve Bank of New York, November 2013; https://www.newyorkfed.org/medialibrary/media/research/staff_reports/sr652.pdf.

Fernald, John G. "Productivity and Potential Output Before, During, and After the Great Recession." NBER Macroeconomics Annual. Volume 29. National Bureau of Economic Research, 2015, pp. 1-51; https://doi.org/10.1086/680580.

Gagnon, Joseph and Holscher, Michael. "Purchases of Agency MBS and Debt." Memorandum to the Federal Open Market Committee, Board of Governors of the Federal Reserve System, Division of Monetary Affairs, Federal Reserve Bank of New York, December 5, 2008; https://www.federalreserve.gov/monetarypolicy/files/FOMC20081212memo17.pdf.

Gagnon, Joseph; Raskin, Matthew; Remache, Julie and Brian, Sack. "The Financial Market Effects of the Federal Reserve's Large-Scale Asset Purchases." International Journal of Central Banking, March 2011, 7, pp. 3-43; https://www.ijcb.org/journal/ijcb11q1a1.pdf.

Gertler, Mark and Karadi, Peter. "QE 1 vs. 2 vs. 3 ...: A Framework for Analyzing Large-Scale Asset Purchases as a Monetary Policy Tool." International Journal of Central Banking, January 2013, 9, pp. 5-53; https://www.ijcb.org/journal/ijcb13q0a1.pdf.

Gilchrist, Simon and Zakrajšek, Egon. "The Impact of the Federal Reserve's Large-Scale Asset Purchase Programs on Corporate Credit Risk." Journal of Money, Credit, and Banking, December 2013, 45, pp. 29-57; https://doi.org/10.1111/jmcb.12070. 


\section{Caldara, Gagnon, Martínez-García, Neely}

Gordon, Robert J. "Secular Stagnation: A Supply-Side View." American Economic Review, 2015, 105(5), pp. 54-59; https://cpb-us-e1.wpmucdn.com/sites.northwestern.edu/dist/6/5500/files/2021/04/SecularStagnation.pdf.

Greenlaw, David; Hamilton, James D.; Harris, Ethan and West, Kenneth D. "A Skeptical View of the Impact of the Fed's Balance Sheet." NBER Working Paper Series 24687, National Bureau of Economic Research, June 2018; https://doi.org/10.3386/w24687.

Greenwood, Robin; Hanson, Samuel; Rudolph, Joshua S. and Summers, Lawrence H. "Government Debt Management at the Zero Lower Bound." Hutchins Center on Fiscal and Monetary Policy Working Paper 5, Brookings Institution, September 30, 2014; https://www.brookings.edu/wp-content/uploads/2016/06/30 government debt management zlb.pdf.

Greenwood, Robin, and Vayanos, Dimitri. "Bond Supply and Excess Bond Returns." Review of Financial Studies, March 2014, 27(3), pp. 663-713; https://doi.org/10.1093/rfs/hht133.

Grossman, Valerie; Mack, Adrienne and Martínez-García, Enrique. "A Contribution to the Chronology of Turning Points in Global Economic Activity (1980-2012)." Journal of Macroeconomics, December 2015, 46, pp. 170-85; https://doi.org/10.1016/j.jmacro.2015.09.003.

Grossman, Valerie; Martínez-García, Enrique; Wynne, Mark A. and Zhang, Ren. "Ties that Bind: Estimating the Natural Rate of Interest for Small Open Economies." Journal of International Money and Finance, May 2021, 113, 102315; https://doi.org/10.1016/j.jimonfin.2020.102315.

Gust, Christopher; Herbst, Edward; López-Salido, David and Smith, Matthew E. "The Empirical Implications of the Interest-Rate Lower Bound." American Economic Review, 2017, 107, pp. 1971-2006; https://doi.org/10.1257/aer.20121437.

Haldane, Andrew; Roberts-Sklar, Matt; Wieladek, Tomasz and Young, Chris. "QE: The Story So Far." Staff Working Paper 624, Bank of England, October 2016; https://doi.org/10.2139/ssrn.2858204.

Hamilton, James D. and Wu, Jing Cynthia. "The Effectiveness of Alternative Monetary Policy Tools in a Zero Lower Bound Environment." Journal of Money, Credit, and Banking, February 2012, 44(1), pp. 3-46;

https://doi.org/10.1111/j.1538-4616.2011.00477.x.

Hesse, Henning; Hofmann, Boris and Weber, James Michael. "The Macroeconomic Effects of Asset Purchases Revisited." Journal of Macroeconomics, December 2018, 58, pp. 115-38; https://doi.org/10.1016/j.jmacro.2018.05.010.

Holston, Kathryn; Laubach, Thomas and Williams, John C. "Measuring the Natural Rate of Interest: International Trends and Determinants." Journal of International Economics, May 2017, 108, S59-S75; https://doi.org/10.1016/j.jinteco.2017.01.004.

Ihrig, Jane; Klee, Elizabeth; Li, Canlin; Wei, Min and Kachovec, Joe. "Expectations about the Federal Reserve's Balance Sheet and the Term Structure of Interest Rates." International Journal of Central Banking, March 2018, 14, pp. 341-90; https://www.ijcb.org/journal/ijcb18q1a8.pdf.

Joyce, Michael A.S. and Tong, Matthew. "QE and the Gilt Market: A Disaggregated Analysis." Economic Journal, November 2012, 122, pp. F348-84: https://doi.org/10.1111/j.1468-0297.2012.02552.x.

Kabukcuoglu, Ayse and Martínez-García, Enrique. "Inflation as a Global Phenomenon-Some Implications for Inflation Modelling and Forecasting." Journal of Economic Dynamics and Control, February 2018, 87, pp. 46-73; https://doi.org/10.1016/j.jedc.2017.11.006.

Kashkari, Neel. "Taylor Rule Would Have Kept Millions Out of Work." Medium (blog), January 5, 2017; https://medium.com/@neelkashkari/taylor-rule-would-have-kept-millions-out-of-work-9ab31fd826bf.

Kiley, Michael T. "The Response of Equity Prices to Movements in Long-Term Interest Rates Associated with Monetary Policy Statements: Before and After the Zero Lower Bound." Journal of Money, Credit, and Banking, August 2014, 46(5), pp. 1057-71; https://doi.org/10.1111/jmcb.12129.

Kiley, Michael T. "Quantitative Easing and the 'New Normal' in Monetary Policy." Manchester School, September 2018, 86, pp. 21-49; https://doi.org/10.1111/manc.12238.

Krugman, Paul R. "It's Baaack: Japan's Slump and the Return of the Liquidity Trap." Brookings Papers on Economic Activity, 1998, 1998(2), pp. 137-205; https://doi.org/10.2307/2534694. 
Kuroda, Haruhiko. "Outlook for Economic Activity and Prices and Monetary Policy." Speech to a meeting held by the Naigai Josei Chosa Kai (Research Institute of Japan), Tokyo, Japan, May 17, 2019; https://www.boj.or.jp/en/announcements/press/koen_2019/data/ko190517a1.pdf.

Kurtzman, Robert J.; Luck, Stephan and Zimmermann, Thomas. "Did QE Lead Banks to Relax Their Lending Standards? Evidence from the Federal Reserve's LSAPs." Journal of Banking and Finance, 2018; https://doi.org/10.1016/j.jbankfin.2018.08.009.

Kuttner, Kenneth N. "Outside the Box: Unconventional Monetary Policy in the Great Recession and Beyond." Journal of Economic Perspectives, Fall 2018, 32, pp. 121-46; https://doi.org/10.1257/jep.32.4.121.

Lo Duca, Marco; Nicoletti, Giulio and Martinez, Ariadna Vidal. "Global Corporate Bond Issuance: What Role for US Quantitative Easing?" Journal of International Money and Finance, February 2016, 60, pp. 114-50; https://doi.org/10.1016/j.jimonfin.2015.07.013.

Lombardi, Domenico; Siklos, Pierre and St. Amand, Samantha. "A Survey of The International Evidence and Lessons Learned About Unconventional Monetary Policies: Is A 'New Normal' In Our Future?" Journal of Economic Surveys, December 2018, 32, pp. 1229-56; https://doi.org/10.1111/joes.12293.

Martínez-García, Enrique. "Modeling Time-Variation Over the Business Cycle (1960-2017): An International Perspective." Studies in Nonlinear Dynamics \& Econometrics, December 2018, 22, pp. 1-25; https://doi.org/10.1515/snde-2017-0101.

Martínez-García, Enrique. "Good Policies or Good Luck? New Insights on Globalization and the International Monetary Policy Transmission Mechanism." Computational Economics, June 2019, 54, pp. 419-54; https://doi.org/10.1007/s10614-017-9746-9.

McCauley, Robert N. and Ueda, Kazuo. "Government Debt Management at Low Interest Rates." BIS Quarterly Review June 2009, pp. 35-51; https://www.bis.org/publ/qtrpdf/r_qt0906e.htm.

Neely, Christopher J. "Unconventional Monetary Policy Had Large International Effects." Journal of Banking and Finance, March 2015, 52, pp. 101-11; https://doi.org/10.1016/j.jbankfin.2014.11.019.

Neely, Christopher J. “How Persistent Are Unconventional Monetary Policy Effects?” Working Paper 2014-004C, Federal Reserve Bank of St. Louis, November 2020; https://doi.org/10.20955/wp.2014.004.

Raskin, Matthew. "The Effects of the Federal Reserve's Date-Based Forward Guidance." Finance and Economics Discussion Series 2013-37, Board of Governors of the Federal Reserve System, May 9, 2013; https://www.federalreserve.gov/econres/feds/the-effects-of-the-federal-reserve39s-date-based-forward-guidance.htm.

Rodnyansky, Alexander and Darmouni, Olivier M. "The Effects of Quantitative Easing on Bank Lending Behavior." Review of Financial Studies, November 2017, 30, pp. 3858-87; https://doi.org/10.1093/rfs/hhx063.

Shirakawa, Masaaki. "Demographic Changes and Macroeconomic Performance: Japanese Experiences." Remarks at the Institute for Monetary and Economic Studies at the Bank of Japan, Tokyo, Japan, May 30, 2012; https://www.bis.org/review/r120531e.pdf.

Sims, Eric R. and Wu, Jing Cynthia. "Evaluating Central Banks' Tool Kit: Past, Present, and Future." NBER Working Paper Series 26040, National Bureau of Economic Research, July 2019; https://doi.org/10.3386/w26040.

Swanson, Eric T. "Let's Twist Again: A High-Frequency Event-study Analysis of Operation Twist and Its Implications for QE2." Brookings Papers on Economic Activity, Spring 2011, pp. 151-188; https://doi.org/10.1353/eca.2011.0006.

Swanson, Eric T. "The Federal Reserve Is Not Very Constrained by the Lower Bound on Nominal Interest Rates." NBER Working Paper Series 25123, National Bureau of Economic Research, October 2018; https://doi.org/10.3386/w25123.

Swanson, Eric T. "Measuring the Effects of Federal Reserve Forward Guidance and Asset Purchases on Financial Markets." Journal of Monetary Economics, March 2021, 118, pp. 32-53; https://doi.org/10.1016/j.jmoneco.2020.09.003.

Swanson, Eric T. and Williams, John C. "Measuring the Effect of the Zero Lower Bound on Medium- and Long-Term Interest Rates." American Economic Review, October 2014, 104, pp. 3154-85; https://doi.org/10.1257/aer.104.10.3154. 


\section{Caldara, Gagnon, Martínez-García, Neely}

Taylor, John B. "Discretion Versus Policy Rules in Practice." Carnegie-Rochester Conference Series on Public Policy, 1993, 39, pp. 195-214; https://doi.org/10.1016/0167-2231(93)90009-L.

Walentin, Karl. "Business Cycle Implications of Mortgage Spreads." Journal of Monetary Economics, October 2014, 67, pp. 62-77; https://doi.org/10.1016/j.jmoneco.2014.07.005.

Weale, Martin and Wieladek, Tomasz. "What Are the Macroeconomic Effects of Asset Purchases?" Journal of Monetary Economics, April 2016, 79, pp. 81-93; https://doi.org/10.1016/j.jmoneco.2016.03.010.

Williams, John C. "Monetary Policy at the Zero Lower Bound: Putting Theory into Practice." Hutchins Center on Fiscal and Monetary Policy Working Paper, Brookings Institution, January 16, 2014;

https://www.brookings.edu/wp-content/uploads/2016/06/16-monetary-policy-zero-lower-bound-williams.pdf.

Wright, Jonathan H. "What Does Monetary Policy Do to Long-Term Interest Rates at the Zero Lower Bound?" Economic Journal, November 2012, 122, pp. F447-66; https://doi.org/10.1111/j.1468-0297.2012.02556.x.

Wu, Jing Cynthia and Xia, Fan Dora. "Measuring the Macroeconomic Impact of Monetary Policy at the Zero Lower Bound." Journal of Money, Credit and Banking, March-April 2016, 48(2-3), pp. 253-91; https://doi.org/10.1111/jmcb.12300.

Wynne, Mark A. and Zhang, Ren. "Measuring the World Natural Rate of Interest." Economic Inquiry, January 2018, 56(1), 530-544; https://doi.org/10.1111/ecin.12500.

Yellen, Janet. "Inflation Dynamics and Monetary Policy." Speech delivered at the Philip Gamble Memorial Lecture, University of Massachusetts, Amherst, MA, September 24, 2015; https://www.federalreserve.gov/newsevents/speech/yellen20150924a.htm.

Yellen, Janet. "The Economic Outlook and the Conduct of Monetary Policy." Speech delivered at the Stanford Institute for Economic Policy Research, Stanford University, Stanford, CA, January 19, 2017; https://www.federalreserve.gov/newsevents/speech/yellen20170119a.htm. 